\title{
Covid 19 Salgın Sürecinin Çocuklar Üzerindeki Etkileri
}

\author{
Effects of Covid 19 Pandemic on Children
}

Oktay AYDIN

\section{ÖZ}

Bu araştırmanın amacı, ebeveyn görüşlerine göre, Covid 19 salgın sürecinin çocukların günlük yaşam alışkanlıkları, duygudurumları, sosyal ilişkileri ve uzaktan eğitimle ilgili davranışları üzerindeki etkilerini incelemektir.

Araştırmaya 749’u anne, 116 ’sı baba olmak üzere toplam 876 ebeveyn katılmıştır. Ebeveynlerin 443 'ünün çocuğu erkek, 433 'ünün çocuğu ise kızdır. Veri toplamak amacıyla araştırmacı tarafından geliştirilen anket kullanılmıştır. Anket 4 bölüm ve 16 sorudan oluşmuştur. Birinci bölüm çocukların günlük yaşantıları, ikinci bölüm duygudurumları, üçüncü bölüm sosyal ilişkileri ve dördüncü bölüm ise uzaktan eğitimle ilgili davranışlarına yönelik sorulardan oluşmuştur.

Araştırmadan elde edilen bulgular şöyledir:

Çocukların günlük yaşam alışkanları ile ilgili olarak, uyku düzenlerinde, yemek yeme düzenlerinde, kıyafet giyip çıkarma davranışlarında olumsuz yönde değişiklikler olmuş, temizlik alışkanlıklarında ise olumlu yönde değişiklikler olmuştur. Duygudurumları ile ilgili olarak, kaygı, öfke ve korku düzeylerinde artış olmuş, mutluluk (neşe) düzeyleri azalmıştır. Sosyal ilişkiler ile ilgili olarak, anne, baba ve kardeşlerle ilişkileri olumsuz yönde (tepkisel, içine kapanık, az iletişim kurma, değişken davranışlar sergileme vb.) değişmiş, öğretmenlerini ise özlemişlerdir. Uzaktan eğitime yönelik davranışları ile ilgili olarak, çocukların büyük bölümünün uzaktan eğitime katıldığı belirlenmiştir. Bununla birlikte, çocukların büyük çoğunluğunun uzaktan eğitime yeterince alışamadığı, yarıdan fazlasının öğrenme kalitesinin iyi olmadığı, yaklaşık yarısının ödev yapma sorunları yaşadığı belirlenmiştir.

Anahtar Kelimeler: Covid-19, pandemi, salgın, uzaktan eğitim, online eğitim, pandemide çocuklar, pandemide ebveynler.

\section{ABSTRACT}

The aim of this research, in parental opinion, is to examine the effects of the Covid 19 pandemic on children's daily life habits, moods, social relationships and behaviors related to distance education.

A total of 876 parents participated in the study, including 749 mothers and 116 fathers. Of the parents, 443 had a boy and 433 had a child. A survey developed by the researcher was used to collect data. The survey consisted of 4 sections and 16 questions. The first part consisted of questions about children's daily lives, the second part consisted of moods, the third part consisted of questions about social relations and the fourth part consisted of questions about their behavior related to distance education.

The findings from the study are as follows:

There were negative changes in children's daily habits of life, sleep patterns, eating patterns, clothing and removal behaviors, and positive changes in cleaning habits. Regarding moods, there was an increase in anxiety levels, anger levels and fear levels, and happiness (joy) levels decreased. Regarding social relations, their relationships with mother, father and siblings changed negatively (reactive, withdrawn, under-communicating, exhibiting variable behaviors, etc.) and they missed their teachers. In relation to their behavior towards distance education, it has been determined that the majority of children participate in distance education. However, it has been determined that the vast majority of children are not accustomed to distance education enough, more than half have poor learning quality, and half have problems doing homework.

Keywords: Covid-19, pandemi, distance education, online education, children in the pandemic, parents in the pandemic. 


\section{GİRIŞ VE PROBLEM}

Covid 19 salgın süreci, dünyanın son yıllarda yaşadığı en önemli sorunlarından biri olmuştur. Bütün dünya için kitlesel bir travma etkisi yaratan salgın, bir çok alanda olumsuz etkilere yol açmıştır. Sosyal ve ekonomik dünyada derin izler bırakan virüs salgını nedeniyle insanların günlük yaşamları, alışkanlıkları, davranış biçimleri ve ilişkileri beklenmedik düzeyde değişmek zorunda kalmıştır.

Dünya Sağlık Örgütünün verilerine göre, 24.10.2021 tarihi itibariyle covid 19 nedeniyle bütün dünyada hasta olanların toplam sayısı 242.348.657, hayatını kaybedenlerin sayısı 4.927.723’tür. Ülkemizde ise hasta olanların sayısı 7.772.604, hayatını kaybedenlerin sayısı ise 68.472 olmuştur (WHO, 2021). Salgının bu boyutlarına bakıldığında hem dünyada hem de ülkemizde kısa, orta ve uzun vadeli sonuçlar doğurması kaçınılmaz görünmektedir. Salgın sürecinde bütün dünyada pek çok beklenmeyen değişiklik yaşanmıştır. İnsanların belirli zaman dilimlerinde evde kalmaları istenmiş, işyerleri kapatılmış, ekonomik sistem yavaşlatılmış, evden çalışma şekli gelişmiş, ulaşım kısıtlanmış, okullar uzaktan eğitim yapmaya başlamıştır.

Dünya Bankası̉nın 157 ülke hakkında verileri kullanarak yaptığı değerlendirmelere göre, covid 19 nedeniyle yaşanan okul kapanışları bir milyardan fazla öğrenciyi okul dışında bırakmıştır. Bu da küresel düzeyde okullaşma düzeyinde azalma olacağı ve öğrenme faaliyetlerinin azalacağını ortaya koymaktadır. Ayrıca, ilköğretimden ortaöğretime kadar 7 milyona yakın öğrencinin, okulu bırakabileceğinden söz edilmektedir. Küresel olarak, 5 aylık bir okul kapanmasının, bugün itibariyle 10 trilyon dolar düzeyinde öğrenme kayıplarına neden olabileceği vurgulanmaktadır (The World Bank, 2021).

Salgının bütün yaş grupları üzerinde olumsuz etkileri olduğu açıktır. Bununla birlikte salgının aileler üzerindeki ekonomik ve sosyal etkileri, uzun karantina ve sosyal izolasyon süreçleri, uzaktan eğitime erişimde yaşanan sıkıntılar ve kayıt altına alınamayan ev içi şiddet gibi durumlar çocukların da salgından etkilenen kırılgan yaş gruplarından biri olduğunu göstermektedir (Akkan, 2020). Nitekim, covid 19 salgını sonrasında 188 ülkede okullar kapatılmış, dünyadaki öğrencilerin yaklaşık \%90’’ olumsuz yönde etkilenmiştir (Lee, 2020). Bu tür afetlerin, çocukların psikolojik işleyişi, duygusal uyumları, sağlığı ve gelişim çizgileri üzerinde kısa ve uzun vadeli etkilere neden olma potansiyeli de yüksektir (Schonfeld ve Demaria, 2015). Bu süreçte haber kaynaklarında doğru ya da asılsız bilgilerin paylaşımı yüksek sayılara ulaşmış; bu da çocuk, ergen ve yetişkinlerde önemli bir stres kaynağı olmuştur (Türk, 2020).

Covid 19 enfeksiyonuna yakalanan aile bireylerinde, diğer aile bireylerine bulaştırmayı önlemek amacıyla ev içi hijyenin etkinliğini ve devamlılığını sağlamak, fiziksel mesafeyi koruyabilmek, evde maske kullanmak gibi zorluklarla beraber, enfeksiyonu geçiren aile bireyinin vefatı, diğer aile bireylerinin de hastalanması, alınan önlemlerin alışılmış yaşam tarzına uymaması gibi nedenlerden dolayı pek çok ruhsal zorluk da yaşanmıştır (Çelik ve Çak, 2021). Bu süreç tüm dünyada da benzer etkilerle yaşanmıştır. Nitekim, Birleşmiş Milletler'in 13 Mayıs 2020 Raporu’na göre İtalyan ve İspanyol ebeveynlerin bir çoğu da çocuğun evde tutulma sürecinde duygusal olarak etkilendiğini gözlemlediğini belirtmiştir (UN, 2020).

Küresel ölçekte yaşanan salgın sorununun olumsuz etkileri olmakla birlikte bu riskleri azaltmak ve süreci tersine çevirmek de mümkündür. Bireylerin risk faktörlerini küçümsemeyip bilimsel tedbirlere ve evrensel genel doğrulara uygun hayat tarzı oluşturmaları halinde, bu süreçte yaşanan deneyim olumlu kazanımlara dönüşebilir (Aslan, 2020). Bunun için de sorunun bütün boyutlarıyla ele alınması, analiz edilmesi ve buna uygun çözümlerin geliştirilmesi gerekir.

Salgının temel olarak dört boyutta etkileri olduğu vurgulanmaktadır. Bu boyutlar, yoksullaşma, eğitim, güvenlik, sağlık ve hayatta kalma olarak sıralanmaktadır (Politika Notu, 2020). Salgın sürecinin en etkili olduğu alanlardan biri de eğitimdir. Bütün dünyada olduğu gibi ülkemizde de bu krizin en büyük mağdurlarından biri çocuklar olmuştur. Anaokulu, ilkokul, ortaokul ve lise kademelerinde yaklaşık 18 milyon çocuğun (MEB Strateji Geliştirme Başkanlığı, 2021) eğitim hayatında aktif olarak bulunduğu bu süreçte, okula gidemeyen çocuklar, bilgisayar tabanlı sistemler üzerinden eğitim hayatlarını sürdürmek zorunda kalmıştır. Öyle ki, bu gelişmeler adeta eğitimin anlamını değiştirmiş; öğretmenin, velinin ve öğrencilerin rollerini farklılaştırmıştır.

Sarı ve Nayır (2020)'in pandemi döneminde eğitim sorunları ile ilgili uluslararası raporları inceleyerek yaptığı derleme çalışmasında ulaştığı sonuçlar aşağıdaki şekilde sıralanmıştır: 


\begin{tabular}{|c|c|c|c|c|}
\hline Temalar & Sorunlar-Alt Temalar & Unesco & OECD & Dünya Bankası \\
\hline $\begin{array}{l}\text { Öğrenme-Öğretme Süreciyle } \\
\text { İlgili Sorunlar }\end{array}$ & Öğrenmenin kesintiye uğraması & $\mathrm{X}$ & $\mathrm{X}$ & $\mathrm{X}$ \\
\hline $\begin{array}{l}\text { Öğrenme-Öğretme Süreciyle } \\
\text { İlgili Sorunlar }\end{array}$ & $\begin{array}{l}\begin{array}{l}\text { Uzaktan öğrenmeyi oluşturma, sürdürme ve } \\
\text { geliştirmede zorluklar }\end{array} \\
\end{array}$ & $\mathrm{X}$ & $\mathrm{X}$ & \\
\hline $\begin{array}{l}\text { Öğrenme-Öğretme Süreciyle } \\
\text { İlgili Sorunlar }\end{array}$ & Okul bırakma oranlarındaki artış & $\mathrm{X}$ & & $\mathrm{X}$ \\
\hline $\begin{array}{l}\text { Öğrenme-Öğretme Süreciyle } \\
\text { İlgili Sorunlar }\end{array}$ & Öğrenmeyi ölçmede zorluklar & $\mathrm{X}$ & $\mathrm{X}$ & \\
\hline $\begin{array}{l}\text { Öğrenme-Öğretme Süreciyle } \\
\text { İlgili Sorunlar }\end{array}$ & Müfredat yetersizlikleri & & $\mathrm{X}$ & \\
\hline $\begin{array}{l}\text { Öğrenme-Öğretme Süreciyle } \\
\text { İlgili Sorunlar }\end{array}$ & Eğitime ulaşmada eşitsizlik & & & $\mathrm{X}$ \\
\hline $\begin{array}{l}\text { Öğrenme-Öğretme Süreciyle } \\
\text { İlgili Sorunlar }\end{array}$ & Öğrencilerin öğrenme kayıpları & & $\mathrm{X}$ & $\mathrm{X}$ \\
\hline $\begin{array}{l}\text { Paydaşlardan kaynaklanan } \\
\text { sorunlar }\end{array}$ & Öğretmenler için karışıklık ve stres & $\mathrm{X}$ & & \\
\hline $\begin{array}{l}\text { Paydaşlardan kaynaklanan } \\
\text { sorunlar }\end{array}$ & $\begin{array}{l}\text { Uzaktan eğitim ve hazırlıksız yakalanan ebeveynler } \\
\text { ve öğretmenler }\end{array}$ & $\mathrm{X}$ & $\mathrm{X}$ & \\
\hline $\begin{array}{l}\text { Paydaşlardan kaynaklanan } \\
\text { sorunlar }\end{array}$ & Velilerle iletişim kuramama & & $\mathrm{X}$ & \\
\hline Sağlık Sorunları & Yetersiz beslenme & $\mathrm{X}$ & $\mathrm{X}$ & $\mathrm{X}$ \\
\hline Sağlık Sorunları & $\begin{array}{l}\text { Öğretmen, öğrenci, velilerin kendilerini kötü } \\
\text { hissetmeleri }\end{array}$ & $\mathrm{X}$ & $\mathrm{X}$ & $\mathrm{X}$ \\
\hline Sağlık Sorunları & Şiddete ve sömürüye daha faza maruz kalma & $\mathrm{X}$ & & \\
\hline Sağlık Sorunları & Sosyal izolasyon & $\mathrm{X}$ & & $\mathrm{X}$ \\
\hline Teknolojik sorunlar & Teknolojik yetersizlikler & & $\mathrm{X}$ & \\
\hline Teknolojik sorunlar & Teknolojiye ulaşamama & & $\mathrm{X}$ & \\
\hline Teknolojik sorunlar & Öğretmenlerin teknolojik yetersizlikleri & & $\mathrm{X}$ & \\
\hline Diğer & Çocuk bakımında boşluklar & $\mathrm{X}$ & & \\
\hline Diğer & Yüksek ekonomik maliyetler & $\mathrm{X}$ & & $\mathrm{X}$ \\
\hline Diğer & $\begin{array}{l}\text { Açık kalan okullar ve okul sistemleri üzerinde artan } \\
\text { baskı }\end{array}$ & $X$ & & \\
\hline
\end{tabular}

Bu gelişmeler toplumların ve insanların yeni davranışlar geliştirmesini zorunlu kılmıştır. Öyle görünüyor ki, bu süreçten çok şey öğrenilecektir. Sürecin yarattığı sorunları iyi tanımak ve yeni çözümler üretmek gerekmektedir. Bu noktada eğitim sektörünün de sorumlulukları çoktur. Eğitim sisteminde yakın dönemde öngörülemeyecek pek çok değişikliğin yaşanması artık kaçınılmazdır. Bu nedenle, yaşanan sorunların bir çok açıdan analiz edilmesi ve gerçekçi değerlendirmeler yapılması önemlidir.

$\mathrm{Bu}$ araştırma da, temel olarak salgın sürecinin eğitim sektöründeki etkilerin bir bölümünü ele almaktadır. Özellikle salgının çocuklar üzerindeki etkileri ve çocukların bu süreçte yaşadıkları bilinmelidir. Önümüzdeki yıllar bu bilgiler ışı̆̆ında uzmanları eğitim sorunlarına farklı çözümler üretmeye yöneltecektir. Şüphesiz ki, insanoğlu tarihsel süreçte yaşadığı pek çok soruna çözüm ürettiği gibi bu sürece de özgün çözümler üretecektir. Bu noktada, geleceğin olası çözümlerine katkıda bulunmak için bu tür araştırmalardan elde edilecek sonuçlara ihtiyacımız bulunmaktadır.

Söz konusu ihtiyacın bir ifadesi olarak bu araştırmada, ebeveyn görüşleri doğrultusunda Covid 19 salgın sürecinin çocukların günlük yaşam alışkanlıkları, duygudurumları ve uzaktan eğitime yönelik davranışları üzerindeki etkileri belirlenmeye çalışılmıştır. Araştırmanın cevabını aradığı temel sorular şunlardır:

1. Ebeveyn görüşlerine göre, Covid 19 salgın sürecinin çocukların günlük yaşam alışkanlıkları üzerindeki etkileri nelerdir?

2. Ebeveyn görüşlerine göre, Covid 19 salgın sürecinin çocukların duygudurumları üzerindeki etkileri nelerdir? 
3. Ebeveyn görüşlerine göre, Covid 19 salgın sürecinin çocukların sosyal ilişkileri üzerindeki etkileri nelerdir?

4. Ebeveyn görüşlerine göre, Covid 19 salgın sürecinin çocukların uzaktan eğitimle ilgili davranışları üzerindeki etkileri nelerdir?

\section{Çalışma Grubu}

Araştırmanın çalışma grubunu ilkokul 1-4 ve ortaokul 5-8. sınıfa devam eden öğrencilerin velilerinden oluşan toplam 876 kişi oluşturmaktadır. Çalışma grubu ile ilgili ayrıntılar aşağıdaki gibidir:

\begin{tabular}{|c|c|c|c|}
\hline Kişisel Bilgiler & Cevaplar & $\mathrm{f}$ & $\%$ \\
\hline \multirow{3}{*}{ İkamet edilen il } & İstanbul & 779 & 88,9 \\
\hline & İstanbul dişı & 97 & 11,1 \\
\hline & Toplam & 876 & 100,0 \\
\hline \multirow{4}{*}{ Çocuğa yakınlık düzeyi } & Anne & 749 & 85,5 \\
\hline & Baba & 116 & 13,2 \\
\hline & Cevapsız & 11 & 1,3 \\
\hline & Toplam & 876 & 100,0 \\
\hline \multirow{3}{*}{ Çocuğun cinsiyeti } & $\mathrm{K}$ & 433 & 49,4 \\
\hline & $\mathrm{E}$ & 443 & 50,6 \\
\hline & Toplam & 876 & 100,0 \\
\hline \multirow{4}{*}{ Çocuğun gittiği okul } & Devlet okulu & 166 & 18,9 \\
\hline & Özel okul & 361 & 41,2 \\
\hline & Cevapsız & 349 & 39,8 \\
\hline & Toplam & 876 & 100,0 \\
\hline \multirow{9}{*}{ Çocuğun sınıf düzeyi } & 1. sinif & 139 & 15,9 \\
\hline & 2. sinif & 120 & 13,7 \\
\hline & 3. sinif & 157 & 17,9 \\
\hline & 4. sinif & 98 & 11,2 \\
\hline & 5. sinif & 124 & 14,2 \\
\hline & 6. sinif & 70 & 8,0 \\
\hline & 7. sinif & 84 & 9,6 \\
\hline & 8. sinif & 84 & 9,6 \\
\hline & Toplam & 876 & 100,0 \\
\hline \multirow{6}{*}{ Annenin eğitim durumu } & İlkokul mezunu & 67 & 7,6 \\
\hline & Ortaokul mezunu & 55 & 6,3 \\
\hline & Lise mezunu & 197 & 22,5 \\
\hline & Üniversite mezunu & 441 & 50,3 \\
\hline & Lisans üstü mezunu & 116 & 13,2 \\
\hline & Toplam & 876 & 100,0 \\
\hline \multirow{6}{*}{ Babanın eğitim durumu } & İlkokul mezunu & 65 & 7,4 \\
\hline & Ortaokul mezunu & 62 & 7,1 \\
\hline & Lise mezunu & 207 & 23,6 \\
\hline & Üniversite mezunu & 419 & 47,8 \\
\hline & Lisans üstü mezunu & 123 & 14,0 \\
\hline & Toplam & 876 & 100,0 \\
\hline \multirow{6}{*}{ (Çocuk dahil) kardeş sayısı } & Tek çocuk & 306 & 34,9 \\
\hline & 2 kardeş & 397 & 45,3 \\
\hline & 3 kardeş & 101 & 11,5 \\
\hline & 4 kardeş ve daha fazla & 24 & 2,7 \\
\hline & Cevapsız & 48 & 5,5 \\
\hline & Toplam & 876 & 100,0 \\
\hline \multirow{3}{*}{$\begin{array}{l}\text { Anne-babanın birlikte yaşama } \\
\text { durumu }\end{array}$} & Birlikte yaşıyor & 804 & 91,8 \\
\hline & Ayrı yaşıor & 72 & 8,2 \\
\hline & Toplam & 876 & 100,0 \\
\hline
\end{tabular}




\section{Veri Toplama Araçları}

Araştırmada veri toplamak amacıyla, araştırmacı tarafından hazırlanmış olan "Covid 19 Salgın Etkileri Anketi” kullanılmıştır. Ankette kişisel bilgiler ve salgın sürecinin çocuğun günlük yaşam alışkanlıklarına etkilerini içeren sorular sorulmuştur. Anketin ilk formu, 3 uzmana gönderildi ve uzmanların görüşleri doğrultusunda 2 soruda düzeltme yapıldı, 3 soruda da ifade sorunu giderildi. Düzeltmelerden sonra form web sitesine yüklenmiş ve ebeveynler tarafından doldurulması sağlanmıştır. Salgın sürecinin etkileri ile sorular içeren anketin bölümleri şunlardır:

1. Bölüm: Günlük Hayatla İlgili Davranış ve Alışkanlıklar

2. Bölüm: Duygudurumla İlgili Davranış ve Tepkiler

3. Bölüm: Sosyal Hayatla İlgili Davranış ve Alışkanlıklar

4. Bölüm: Uzaktan Eğitimle İlgili Davranış ve Tepkiler

Anketin her bölümünde 4 soru yer almaktadır. Buna göre, salgın ile ilgili toplam 16 soru sorulmuş ve cevaplar alınmıştır.

\section{Verilerin Toplanması ve Analizi}

Araştırmada veri toplamak amacıyla aşağıdaki aşamalar izlenmiştir:

* Araştırma ile ilgili olarak üniversiteden etik izinler alındı.

* Ölçek formu bir web sitesi üzerinden uygulamaya hazır hale getirildi. Formun başında, araştırmanın amacı, verilerin bilimsel amaçla kullanılacağı ve ad soyad gibi kişisel bilgilerin istenmediği vurgulanarak katılımcılar ile araştırmacı arasında güven ilişkisi oluşturuldu. Araştırmaya sadece gönüllü olanların katılması sağlandı. Toplanan veriler araştırma dışındaki kişilerle paylaşılmadı.

* Yaklaşık 3 hafta içerisinde formların doldurulması sağlandı.

Formlardan elde edilen veriler üzerinde aşağıdaki istatistiksel analizler yapılmıştır:

* Velilerin çocuklarıyla ilgili gözlemlerine ilişkin frekans ve yüzde hesaplamaları yapılmıştır.

* Velilerin gözlem ve görüşlerinin cinsiyet, okul türü ve öğretim kademesine göre karşılaştırmasını yapmak amacıyla ki-kare analizleri yapılmıştır.

\section{BULGULAR}

Araştırmanın birinci sorusu, "Ebeveynlerin görüşlerine göre, Covid 19 salgın sürecinin çocukların günlük yaşam alışkanlıkları, duygudurumları ve uzaktan eğitime yönelik davranışları üzerindeki etkileri nelerdir?” olarak ifade edilmiştir. Soruyla ilgili bulgular şöyledir:

\section{Salgın sürecinin çocukların günlük yaşam alışkanlıklarına etkileri ile ilgili bulgular}

Covid 19 salgın sürecinin çocukların günlük yaşam alıskanlıklarına etkileri ile ilgili ebeveynlerin görüşleri aşağıdaki gibidir:

Tablo 1a ve 1b, "Çocuğun uyku düzeni salgın öncesi zamana göre ne yönde değişti?" sorusuna verilen cevaplar ile ilgili bulguları göstermektedir.

Tablo 1a: “Çocuğun uyku düzeni salgın öncesi zamana göre ne yönde değişti?” sorusuna verilen cevaplar

\begin{tabular}{|c|c|c|}
\hline & $\mathrm{f}$ & $\%$ \\
\hline Çok olumlu yönde değişiklik oldu & 10 & 1,1 \\
\hline Biraz olumlu yönde değişiklik oldu & 21 & 2,4 \\
\hline Herhangi bir değişiklik olmadı & 340 & 38,8 \\
\hline Biraz olumsuz yönde değişiklik oldu & 374 & 42,7 \\
\hline Çok olumsuz yönde değişiklik oldu & 131 & 15,0 \\
\hline Toplam & 876 & 100,0 \\
\hline
\end{tabular}


Tablo 1a’ya göre, çocukların uyku düzenleri salgın öncesine göre çok olumlu ve biraz olumlu yönde değişti diyen ebeveynlerin toplam oranı \%3,5 iken biraz olumsuz ve çok olumsuz yönde değiști diyenlerin toplam oranı \%57,7'dir. Herhangi bir değişiklik olmadığını söyleyenlerin oranı ise \%38,8'dir. Genel olarak ifade edilecek olursa, çocukların uyku düzeninin salgın öncesi zamana göre daha çok olumsuz yönde değiştiği söylenebilir.

Tablo 1b: "Çocuğun uyku düzeni salgın öncesi zamana göre ne yönde değişti?" sorusuna verilen cevapların çocuğun cinsiyeti, gittiği okul türü ve öğretim kademesi ile ilişkisi

\begin{tabular}{|c|c|c|c|c|c|c|c|c|c|c|c|}
\hline & & & 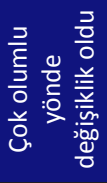 & 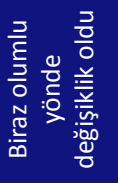 & 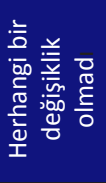 & 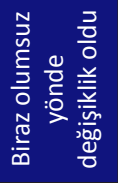 & 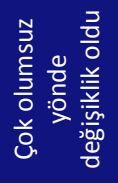 & $\begin{array}{l}\frac{\varepsilon}{\sigma} \\
\frac{\pi}{0} \\
\stackrel{0}{\circ}\end{array}$ & $\chi$ & sd & $p$ \\
\hline \multirow{6}{*}{ 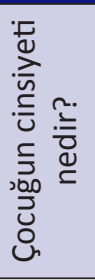 } & \multirow{2}{*}{ K } & $\mathrm{n}$ & 5 & 9 & 159 & 193 & 67 & 433 & \multirow{6}{*}{$2,192^{\mathrm{a}}$} & \multirow{6}{*}{4} & \multirow{6}{*}{,701 } \\
\hline & & $\%$ & $1,2 \%$ & $2,1 \%$ & $36,7 \%$ & $44,6 \%$ & $15,5 \%$ & $100,0 \%$ & & & \\
\hline & \multirow{2}{*}{$E$} & $\mathrm{n}$ & 5 & 12 & 181 & 181 & 64 & 443 & & & \\
\hline & & $\%$ & $1,1 \%$ & $2,7 \%$ & $40,9 \%$ & $40,9 \%$ & $14,4 \%$ & $100,0 \%$ & & & \\
\hline & \multirow{2}{*}{ Toplam } & $\mathrm{n}$ & 10 & 21 & 340 & 374 & 131 & 876 & & & \\
\hline & & $\%$ & $1,1 \%$ & $2,4 \%$ & $38,8 \%$ & $42,7 \%$ & $15,0 \%$ & $100,0 \%$ & & & \\
\hline \multirow{6}{*}{ 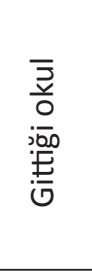 } & \multirow{2}{*}{ Devlet okulu } & $\mathrm{n}$ & 7 & 14 & 170 & 227 & 97 & 515 & \multirow{6}{*}{$25,044 a$} & \multirow{6}{*}{4} & \multirow{6}{*}{,000 } \\
\hline & & $\%$ & $1,4 \%$ & $2,7 \%$ & $33,0 \%$ & $44,1 \%$ & $18,8 \%$ & $100,0 \%$ & & & \\
\hline & \multirow{2}{*}{ Özel okul } & $\mathrm{n}$ & 3 & 7 & 170 & 147 & 34 & 361 & & & \\
\hline & & $\%$ &, $8 \%$ & $1,9 \%$ & $47,1 \%$ & $40,7 \%$ & $9,4 \%$ & $100,0 \%$ & & & \\
\hline & \multirow{2}{*}{ Toplam } & $\mathrm{n}$ & 10 & 21 & 340 & 374 & 131 & 876 & & & \\
\hline & & $\%$ & $1,1 \%$ & $2,4 \%$ & $38,8 \%$ & $42,7 \%$ & $15,0 \%$ & $100,0 \%$ & & & \\
\hline \multirow{6}{*}{$\begin{array}{l}\stackrel{0}{E} \\
\frac{0}{0} \\
\stackrel{0}{\square}\end{array}$} & \multirow{2}{*}{ ilkokul } & $\mathrm{n}$ & 8 & 15 & 207 & 213 & 71 & 514 & \multirow{6}{*}{$5,508 a$} & \multirow{6}{*}{4} & \multirow{6}{*}{ 239 } \\
\hline & & $\%$ & $1,6 \%$ & $2,9 \%$ & $40,3 \%$ & $41,4 \%$ & $13,8 \%$ & $100,0 \%$ & & & \\
\hline & \multirow{2}{*}{ Ortaokul } & $\mathrm{n}$ & 2 & 6 & 133 & 161 & 60 & 362 & & & \\
\hline & & $\%$ & ,6\% & $1,7 \%$ & $36,7 \%$ & $44,5 \%$ & $16,6 \%$ & $100,0 \%$ & & & \\
\hline & \multirow{2}{*}{ Toplam } & $\mathrm{n}$ & 10 & 21 & 340 & 374 & 131 & 876 & & & \\
\hline & & $\%$ & $1,1 \%$ & $2,4 \%$ & $38,8 \%$ & $42,7 \%$ & $15,0 \%$ & $100,0 \%$ & & & \\
\hline
\end{tabular}

Tablo 1b, “Çocuğun uyku düzeni salgın öncesi zamana göre ne yönde değişti?” sorusuna verilen cevapların çocuğun cinsiyetine, gittiği okul türüne ve öğretim kademesine göre farklılaşma durumunu ortaya koymaktadır. Elde edilen bulgular şunlardır:

* "Çocuğun uyku düzeni salgın öncesi zamana göre ne yönde değişti?” sorusuna verilen cevaplar ile çocuğun cinsiyeti arasında anlamlı bir bağıntı yoktur.

* "Çocuğun uyku düzeni salgın öncesi zamana göre ne yönde değişti??" sorusuna verilen cevaplar ile çocuğun gittiği okul türü arasında .01 düzeyinde anlamlı bir bağıntı vardır. Yüzdelik değerlere bakıldığında, çocuğu devlet okuluna giden velilerin çoğu (biraz ve çok olumsuz değişiklik oldu diyenlerin toplamı \%62,9) olumsuz değişiklik olduğunu ifade etmiştir. Çocuğu özel okula giden ebeveynlerin çoğu da (biraz ve çok olumsuz değişiklik oldu diyenlerin toplamı $\% 50,3$ ) olumsuz değişiklik olduğunu ifade etmiştir. Her iki okul türü açısından bakıldığında, çocuğu devlet okuluna giden velileri, özel okula giden velilere göre çok daha olumsuz görüş bildirmişlerdir. İlgi çekici bir diğer sonuç da herhangi bir değişiklik olmadığı kanaatinde olan velilerle ilgilidir. Çocuğu özel okula giden velilerin yüzdesi $(\% 47,1)$, devlet okuluna giden velilerin yüzdesine $(\% 33,0)$ göre daha fazladır. Bir başka ifadeyle, özel okul velileri, çocuğun uyku düzeninde herhangi bir değişiklik olmadığı görüşünü daha fazla ifade etmiştir.

* "Çocuğun uyku düzeni salgın öncesi zamana göre ne yönde değişti?" sorusuna verilen cevaplar ile çocuğun devam ettiği öğretim kademesi/sınıfı arasında anlamlı bir bağıntı yoktur.

Tablo 2a ve 2b, “Çocuğun yemek düzeni salgın öncesi zamana göre ne yönde değişti?” sorusuna verilen cevaplar ile ilgili bulguları göstermektedir. 
Tablo 2a: “Çocuğun yemek düzeni salgın öncesi zamana göre ne yönde değiști?”

\begin{tabular}{l|c|c}
\hline & f & $\%$ \\
Çok olumlu yönde değişiklik oldu & 36 & 4,1 \\
Biraz olumlu yönde değişiklik oldu & 77 & 8,8 \\
Herhangi bir değişiklik olmadı & 409 & 46,7 \\
Biraz olumsuz yönde değişiklik oldu & 261 & 29,8 \\
Çok olumsuz yönde değişiklik oldu & 93 & 10,6 \\
Toplam & 876 & 100,0 \\
\hline
\end{tabular}

Tablo 2a’ya göre, çocukların yemek düzenleri salgın öncesine göre çok olumlu ve biraz olumlu yönde değişti diyen ebeveynlerin toplam oranı \%5,9 iken biraz olumsuz ve çok olumsuz yönde değişti diyenlerin toplam oranı \%40,4'tür. Herhangi bir değişiklik olmadığını söyleyenlerin oranı ise \%46,7'dir. Genel olarak değerlendirildiğinde, çocukların yemek düzenlerinin salgın öncesi zamana göre daha olumsuz yönde değiştiği görülmektedir.

Tablo 2b: "Çocuğun yemek düzeni salgın öncesi zamana göre ne yönde değişti?” sorusuna verilen cevapların çocuğun cinsiyeti, gittiği okul türü ve öğretim kademesi ile ilişkisi

\begin{tabular}{|c|c|c|c|c|c|c|c|c|c|c|c|}
\hline & & & 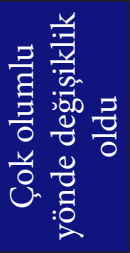 & 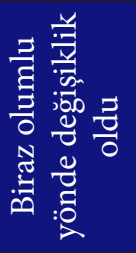 & 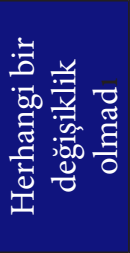 & 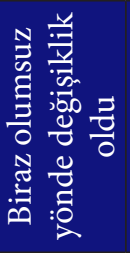 & 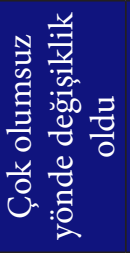 & 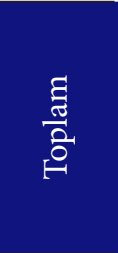 & $\chi$ & $\mathrm{sd}$ & $\mathrm{p}$ \\
\hline \multirow{6}{*}{ 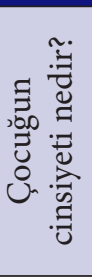 } & \multirow{2}{*}{ K } & $\mathrm{n}$ & 20 & 41 & 198 & 137 & 37 & 433 & \multirow{6}{*}{$5,598 \mathrm{a}$} & \multirow{6}{*}{4} & \multirow{6}{*}{,231 } \\
\hline & & $\%$ & $4,6 \%$ & $9,5 \%$ & $45,7 \%$ & $31,6 \%$ & $8,5 \%$ & $100,0 \%$ & & & \\
\hline & \multirow{2}{*}{$\mathrm{E}$} & $\mathrm{n}$ & 16 & 36 & 211 & 124 & 56 & 443 & & & \\
\hline & & $\%$ & $3,6 \%$ & $8,1 \%$ & $47,6 \%$ & $28,0 \%$ & $12,6 \%$ & $100,0 \%$ & & & \\
\hline & \multirow{2}{*}{ Toplam } & $\mathrm{n}$ & 36 & 77 & 409 & 261 & 93 & 876 & & & \\
\hline & & $\%$ & $4,1 \%$ & $8,8 \%$ & $46,7 \%$ & $29,8 \%$ & $10,6 \%$ & $100,0 \%$ & & & \\
\hline \multirow{6}{*}{ 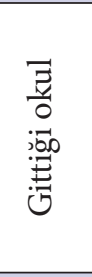 } & \multirow{2}{*}{ Devlet okulu } & $\mathrm{n}$ & 25 & 41 & 235 & 150 & 64 & 515 & \multirow{6}{*}{ 7,010a } & \multirow{6}{*}{4} & \multirow{6}{*}{,135 } \\
\hline & & $\%$ & $4,9 \%$ & $8,0 \%$ & $45,6 \%$ & $29,1 \%$ & $12,4 \%$ & $100,0 \%$ & & & \\
\hline & \multirow{2}{*}{ Özel okul } & $\mathrm{n}$ & 11 & 36 & 174 & 111 & 29 & 361 & & & \\
\hline & & $\%$ & $3,0 \%$ & $10,0 \%$ & $48,2 \%$ & $30,7 \%$ & $8,0 \%$ & $100,0 \%$ & & & \\
\hline & \multirow{2}{*}{ Toplam } & $\mathrm{n}$ & 36 & 77 & 409 & 261 & 93 & 876 & & & \\
\hline & & $\%$ & $4,1 \%$ & $8,8 \%$ & $46,7 \%$ & $29,8 \%$ & $10,6 \%$ & $100,0 \%$ & & & \\
\hline \multirow{6}{*}{$\frac{\mathscr{\Xi}}{\stackrel{\Xi}{\tilde{U}}}$} & \multirow{2}{*}{ İlkokul } & $\mathrm{n}$ & 25 & 50 & 255 & 138 & 46 & 514 & \multirow{6}{*}{$12,119 a$} & \multirow{6}{*}{4} & \multirow{6}{*}{,016 } \\
\hline & & $\%$ & $4,9 \%$ & $9,7 \%$ & $49,6 \%$ & $26,8 \%$ & $8,9 \%$ & $100,0 \%$ & & & \\
\hline & \multirow{2}{*}{ Ortaokul } & $\mathrm{n}$ & 11 & 27 & 154 & 123 & 47 & 362 & & & \\
\hline & & $\%$ & $3,0 \%$ & $7,5 \%$ & $42,5 \%$ & $34,0 \%$ & $13,0 \%$ & $100,0 \%$ & & & \\
\hline & \multirow{2}{*}{ Toplam } & $\mathrm{n}$ & 36 & 77 & 409 & 261 & 93 & 876 & & & \\
\hline & & $\%$ & $4,1 \%$ & $8,8 \%$ & $46,7 \%$ & $29,8 \%$ & $10,6 \%$ & $100,0 \%$ & & & \\
\hline
\end{tabular}

Tablo 2b, “Çocuğun yemek düzeni salgın öncesi zamana göre ne yönde değişti?” sorusuna verilen cevapların çocuğun cinsiyetine, gittiği okul türüne ve öğretim kademesine göre farklılaşma durumunu ortaya koymaktadır. Elde edilen bulgular şöyledir:

* "Çocuğun yemek düzeni salgın öncesi zamana göre ne yönde değişti?” sorusuna verilen cevaplar ile çocuğun cinsiyeti arasında anlamlı bir bağıntı yoktur.

* “Çocuğun yemek düzeni salgın öncesi zamana göre ne yönde değişti?” sorusuna verilen cevaplar ile çocuğun gittiği okul arasında anlamlı bir bağıntı yoktur.

* "Çocuğun yemek düzeni salgın öncesi zamana göre ne yönde değişti?" sorusuna verilen cevaplar ile çocuğun öğretim kademesi arasında .05 düzeyinde anlamlı bir bağıntı vardır. Yüzdelik değerlere bakıldığında, çocuğu ilkokula devam eden ebeveynlerin toplam \%14,6'sı biraz ya da çok olumlu yönde değişiklik olduğunu; toplam \%35,7'si biraz ya da çok olumsuz yönde değişiklik olduğunu ifade etmiş; \%49,6'sı ise bir değişiklik olmadığını belirtmiştir. Çocuğu ortaokula devam eden ebeveynlerin ise toplam \%10,5’i biraz ya da çok olumlu yönde 
değişiklik olduğunu; \%47,0’ı ise biraz ya da çok olumsuz yönde değiş̧iklik olduğunu ifade ederken, \%42,5’i ise bir değişiklik olmadığını ifade etmiştir. Bu sonuçlar dikkate alındığında, hem ilkokula hem de ortaokula devam eden çocukların ebeveynleri, salgın sürecinin çocukların yemek düzenini ya değiştirmediğini ya da olumsuz yönde değiştirdiğini daha çok ifade etmiştir. Özellikle çocukları ortaokula devam eden ebeveynlerin \%13,0’1 çok olumsuz yönde değişiklik olduğunu vurgulamıştır.

Tablo 3a ve 3b, "Çocuğun kıyafetlerini giyip çıkarma davranışları salgın öncesi zamana göre ne yönde değişti?” sorusuna verilen cevaplar ile ilgili bulguları göstermektedir.

Tablo 3a: Çocuğun kıyafetlerini giyip çıkarma davranışları salgın öncesi zamana göre ne yönde değişti?

\begin{tabular}{lcc}
\hline & f & $\%$ \\
\hline Çok olumlu yönde değişiklik oldu & 45 & 5,1 \\
Biraz olumlu yönde değişiklik oldu & 86 & 9,8 \\
Herhangi bir değişiklik olmadı & 501 & 57,2 \\
Biraz olumsuz yönde değişiklik oldu & 194 & 22,1 \\
Çok olumsuz yönde değişiklik oldu & 50 & 5,7 \\
Toplam & 876 & 100,0 \\
\hline
\end{tabular}

Tablo 3a’ya göre, çocukların kıyafetlerini giyip çıkarma davranışları salgın öncesine göre çok olumlu ve biraz olumlu yönde değişti diyen ebeveynlerin toplam oranı \%14,9 iken biraz olumsuz ve çok olumsuz yönde değişti diyenlerin toplam oranı $\% 27,8$ 'dir. Herhangi bir değişiklik olmadığını söyleyenlerin oranı ise $\% 57,2$ 'dir. Genel olarak değerlendirildiğinde, çocukların kıyafet giyip çıkarma davranışlarının salgın öncesi zamana göre olumsuz yönde daha çok değiştiği söylenebilir.

Tablo 3b: “Çocuğun kıyafetlerini giyip çıarma davranışları salgın öncesi zamana göre ne yönde değişti?” sorusuna verilen cevapların çocuğun cinsiyeti, gittiği okul türü ve öğretim kademesi ile ilişkisi

\begin{tabular}{|c|c|c|c|c|c|c|c|c|c|c|c|}
\hline & & & 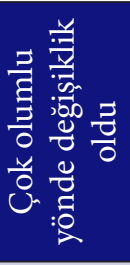 & 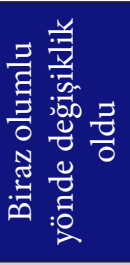 & 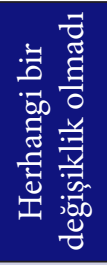 & 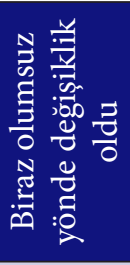 & 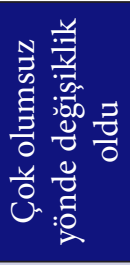 & $\frac{\text { छ }}{\frac{\tilde{z}}{0}}$ & $\chi$ & sd & $\mathrm{p}$ \\
\hline \multirow{6}{*}{ 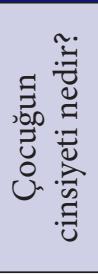 } & \multirow{2}{*}{$\mathrm{K}$} & $\mathrm{n}$ & 26 & 35 & 247 & 101 & 24 & 433 & \multirow{6}{*}{$4,460 \mathrm{a}$} & \multirow{6}{*}{4} & \multirow{6}{*}{,347 } \\
\hline & & $\%$ & $6,0 \%$ & $8,1 \%$ & $57,0 \%$ & $23,3 \%$ & $5,5 \%$ & $100,0 \%$ & & & \\
\hline & \multirow{2}{*}{$\mathrm{E}$} & $\mathrm{n}$ & 19 & 51 & 254 & 93 & 26 & 443 & & & \\
\hline & & $\%$ & $4,3 \%$ & $11,5 \%$ & $57,3 \%$ & $21,0 \%$ & $5,9 \%$ & $100,0 \%$ & & & \\
\hline & \multirow{2}{*}{ Toplam } & $\mathrm{n}$ & 45 & 86 & 501 & 194 & 50 & 876 & & & \\
\hline & & $\%$ & $5,1 \%$ & $9,8 \%$ & $57,2 \%$ & $22,1 \%$ & $5,7 \%$ & $100,0 \%$ & & & \\
\hline \multirow{6}{*}{ 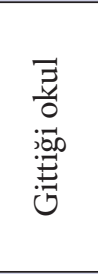 } & \multirow{2}{*}{$\begin{array}{c}\text { Devlet } \\
\text { okulu }\end{array}$} & $\mathrm{n}$ & 39 & 50 & 306 & 89 & 31 & 515 & \multirow{6}{*}{$29,098 \mathrm{a}$} & \multirow{6}{*}{4} & \multirow{6}{*}{,000 } \\
\hline & & $\%$ & $7,6 \%$ & $9,7 \%$ & $59,4 \%$ & $17,3 \%$ & $6,0 \%$ & $100,0 \%$ & & & \\
\hline & \multirow{2}{*}{$\begin{array}{l}\text { Özel } \\
\text { okul }\end{array}$} & $\mathrm{n}$ & 6 & 36 & 195 & 105 & 19 & 361 & & & \\
\hline & & $\%$ & $1,7 \%$ & $10,0 \%$ & $54,0 \%$ & $29,1 \%$ & $5,3 \%$ & $100,0 \%$ & & & \\
\hline & \multirow{2}{*}{ Toplam } & $\mathrm{n}$ & 45 & 86 & 501 & 194 & 50 & 876 & & & \\
\hline & & $\%$ & $5,1 \%$ & $9,8 \%$ & $57,2 \%$ & $22,1 \%$ & $5,7 \%$ & $100,0 \%$ & & & \\
\hline \multirow{6}{*}{ 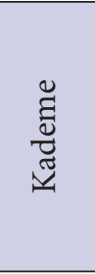 } & \multirow{2}{*}{ İlkokul } & $\mathrm{n}$ & 32 & 59 & 313 & 90 & 20 & 514 & \multirow{6}{*}{$28,614 a$} & \multirow{6}{*}{4} & \multirow{6}{*}{,000 } \\
\hline & & $\%$ & $6,2 \%$ & $11,5 \%$ & $60,9 \%$ & $17,5 \%$ & $3,9 \%$ & $100,0 \%$ & & & \\
\hline & \multirow{2}{*}{ Ortaokul } & $\mathrm{n}$ & 13 & 27 & 188 & 104 & 30 & 362 & & & \\
\hline & & $\%$ & $3,6 \%$ & $7,5 \%$ & $51,9 \%$ & $28,7 \%$ & $8,3 \%$ & $100,0 \%$ & & & \\
\hline & \multirow{2}{*}{ Toplam } & $\mathrm{n}$ & 45 & 86 & 501 & 194 & 50 & 876 & & & \\
\hline & & $\%$ & $5,1 \%$ & $9,8 \%$ & $57,2 \%$ & $22,1 \%$ & $5,7 \%$ & $100,0 \%$ & & & \\
\hline
\end{tabular}

Tablo 3b, “Çocuğun kıyafetlerini giyip çıkarma davranışları salgın öncesi zamana göre ne yönde değişti?” sorusuna verilen cevapların çocuğun cinsiyetine, gittiği okul türüne ve öğretim kademesine göre farklılaşma durumunu ortaya koymaktadır. Elde edilen bulgular şöyledir: 
* “Çocuğun kıyafetlerini giyip çıkarma davranışları salgın öncesi zamana göre ne yönde değişti?” sorusuna verilen cevaplar ile çocuğun cinsiyeti arasında anlamlı bir bağıntı yoktur.

* “Çocuğun kıyafetlerini giyip çıkarma davranışları salgın öncesi zamana göre ne yönde değişti?” sorusuna verilen cevaplar ile çocuğun gittiği okul arasında .01 düzeyinde anlamlı bir bağıntı vardır. Yüzdelik değerlere bakıldığında, devlet okuluna giden çocukların ebeveynlerinin toplam \%13,7’si biraz ve çok olumlu yönde değişiklik olduğu görüşündedir. Toplam \%19,3’ü ise biraz ya da çok olumsuz yönde değişiklik olduğu yönünde görüş bildirmiştir. \%59,4’ü ise bir değişiklik olmadığını belirtmiştir. Özel okula giden çocukların ebeveynlerinin ise toplam \%11,7'si biraz ya da çok olumlu yönde değişiklik oldu derken, toplam \%34,4’ü biraz ya da çok olumsuz yönde değişiklik oldu demiştir. Değiş̧iklik olmadığını söyleyenlerin oranı ise \%54,0'dır. Bu sonuçlara göre, genel olarak bir değişiklik olmadığı yönündeki görüş daha baskındır. Olumsuz yönde değişiklik olduğu görüşünü dile getirenler daha çok özel okula devam eden çocukların ebeveynleridir. Olumlu değişiklik olduğunu söyleyenler ise daha çok devlet okuluna devam eden çocukların ebeveynleridir.

* “Çocuğun kıyafetlerini giyip çıkarma davranışları salgın öncesi zamana göre ne yönde değişti?” sorusuna verilen cevaplar ile çocuğun devam ettiği öğretim kademesi arasında .01 düzeyinde anlamlı bir bağıntı vardır. Yüzdelik değerlere bakıldığında, ilkokula giden çocukların ebeveynlerinin toplam \%17,7'si biraz ve çok olumlu yönde değişiklik olduğu görüşündedir. Toplam \%21,4'ü ise biraz ya da çok olumsuz yönde değişiklik olduğu yönünde görüş bildirmiştir. \%60,9'u ise bir değişiklik olmadığını belirtmiştir. Ortaokula giden çocukların ebeveynlerinin ise toplam \%11,1'i biraz ya da çok olumlu yönde değişiklik oldu derken, toplam \%37,0’ı biraz ya da çok olumsuz yönde değişiklik oldu demiştir. Değişiklik olmadığını söyleyenlerin oranı ise \%51,9'dur. Bu sonuçlara göre, genel olarak bir değişiklik olmadığı yönündeki görüş daha baskındır. Ortaokula devam eden çocukların ebeveynleri, ilkokula devam eden çocukların ebeveynlerine göre daha fazla değişiklik olduğunu belirtmiştir. Olumlu yönde değişiklik olduğu görüşünü dile getirenler daha çok ilkokula devam eden çocukların ebeveynleri iken, olumsuz yönde değişiklik olduğu görüşünü ortaokula devam eden çocukların ebeveynleri ifade etmiştir.

Tablo 4a ve 4b, “Çocuğun temizlik alışkanlıkları salgın öncesi zamana göre ne yönde değişti?” sorusuna verilen cevaplar ile ilgili bulguları göstermektedir.

Tablo 4a: Çocuğun temizlik alışkanlıkları salgın öncesi zamana göre ne yönde değişti?

\begin{tabular}{l|c|c} 
& f & $\%$ \\
\hline Çok olumlu yönde değişiklik oldu & 203 & 23,2 \\
Biraz olumlu yönde değişiklik oldu & 292 & 33,3 \\
Herhangi bir değişiklik olmadı & 280 & 32,0 \\
Biraz olumsuz yönde değişiklik oldu & 88 & 10,0 \\
Çok olumsuz yönde değişiklik oldu & 13 & 1,5 \\
Toplam & 876 & 100,0 \\
\hline
\end{tabular}

Tablo 4a’ya göre, çocukların temizlik alışkanlıkları salgın öncesine göre çok olumlu ve biraz olumlu yönde değişti diyen ebeveynlerin toplam oran $\% 56,5$ iken biraz olumsuz ve çok olumsuz yönde değişti diyenlerin toplam oranı \%11,5’tir. Herhangi bir değişiklik olmadığını söyleyenlerin oranı ise \%32,0'dır. Genel olarak sonuçlara bakıldığında, çocukların temizlik alışkanlıklarının salgın öncesi zamana göre olumlu yönde değiştiği söylenebilir. 
Tablo 4b: “Çocuğun temizlik alışkanlıkları salgın öncesi zamana göre ne yönde değişti?” sorusuna verilen cevapların çocuğun cinsiyeti, gittiği okul türü ve öğretim kademesi ile ilişkisi

\begin{tabular}{|c|c|c|c|c|c|c|c|c|c|c|c|}
\hline & & & 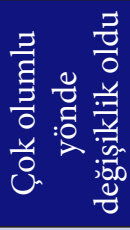 & 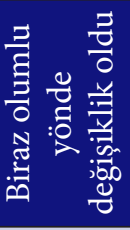 & 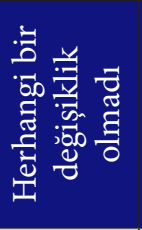 & 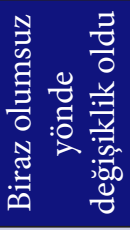 & 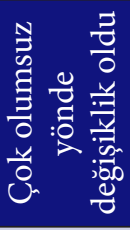 & $\frac{\text { घี }}{\frac{\text { है }}{0}}$ & $\chi$ & sd & $\mathrm{p}$ \\
\hline \multirow{6}{*}{ 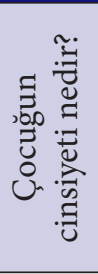 } & \multirow{2}{*}{$\mathrm{K}$} & $\mathrm{n}$ & 107 & 135 & 139 & 46 & 6 & 433 & \multirow{6}{*}{$2,413 a$} & \multirow{6}{*}{4} & \multirow{6}{*}{,660 } \\
\hline & & $\%$ & $24,7 \%$ & $31,2 \%$ & $32,1 \%$ & $10,6 \%$ & $1,4 \%$ & $100,0 \%$ & & & \\
\hline & \multirow{2}{*}{$\mathrm{E}$} & $\mathrm{n}$ & 96 & 157 & 141 & 42 & 7 & 443 & & & \\
\hline & & $\%$ & $21,7 \%$ & $35,4 \%$ & $31,8 \%$ & $9,5 \%$ & $1,6 \%$ & $100,0 \%$ & & & \\
\hline & \multirow{2}{*}{ Toplam } & $\mathrm{n}$ & 203 & 292 & 280 & 88 & 13 & 876 & & & \\
\hline & & $\%$ & $23,2 \%$ & $33,3 \%$ & $32,0 \%$ & $10,0 \%$ & $1,5 \%$ & $100,0 \%$ & & & \\
\hline \multirow{6}{*}{$\begin{array}{l}\vec{Z} \\
\frac{7}{0} \\
i .00 \\
: \stackrel{0}{0} \\
0\end{array}$} & \multirow{2}{*}{$\begin{array}{l}\text { Devlet } \\
\text { okulu }\end{array}$} & $\mathrm{n}$ & 158 & 167 & 138 & 46 & 6 & 515 & \multirow{6}{*}{$43,531 a$} & \multirow{6}{*}{4} & \multirow{6}{*}{,000 } \\
\hline & & $\%$ & $30,7 \%$ & $32,4 \%$ & $26,8 \%$ & $8,9 \%$ & $1,2 \%$ & $100,0 \%$ & & & \\
\hline & \multirow{2}{*}{$\begin{array}{l}\text { Özel } \\
\text { okul }\end{array}$} & $\mathrm{n}$ & 45 & 125 & 142 & 42 & 7 & 361 & & & \\
\hline & & $\%$ & $12,5 \%$ & $34,6 \%$ & $39,3 \%$ & $11,6 \%$ & $1,9 \%$ & $100,0 \%$ & & & \\
\hline & \multirow{2}{*}{ Toplam } & $\mathrm{n}$ & 203 & 292 & 280 & 88 & 13 & 876 & & & \\
\hline & & $\%$ & $23,2 \%$ & $33,3 \%$ & $32,0 \%$ & $10,0 \%$ & $1,5 \%$ & $100,0 \%$ & & & \\
\hline \multirow{6}{*}{ 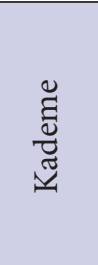 } & \multirow{2}{*}{ İlkokul } & $\mathrm{n}$ & 142 & 184 & 147 & 35 & 6 & 514 & \multirow{6}{*}{$31,122 \mathrm{a}$} & \multirow{6}{*}{4} & \multirow{6}{*}{,000 } \\
\hline & & $\%$ & $27,6 \%$ & $35,8 \%$ & $28,6 \%$ & $6,8 \%$ & $1,2 \%$ & $100,0 \%$ & & & \\
\hline & \multirow{2}{*}{ Ortaokul } & $\mathrm{n}$ & 61 & 108 & 133 & 53 & 7 & 362 & & & \\
\hline & & $\%$ & $16,9 \%$ & $29,8 \%$ & $36,7 \%$ & $14,6 \%$ & $1,9 \%$ & $100,0 \%$ & & & \\
\hline & \multirow{2}{*}{ Toplam } & $\mathrm{n}$ & 203 & 292 & 280 & 88 & 13 & 876 & & & \\
\hline & & $\%$ & $23,2 \%$ & $33,3 \%$ & $32,0 \%$ & $10,0 \%$ & $1,5 \%$ & $100,0 \%$ & & & \\
\hline
\end{tabular}

Tablo 4b, "Çocuğun temizlik alışkanlıkları salgın öncesi zamana göre ne yönde değişti?” sorusuna verilen cevapların çocuğun cinsiyetine, gittiği okul türüne ve öğretim kademesine göre farklılaşma durumunu ortaya koymaktadır. Elde edilen bulgular şöyledir:

* “Çocuğun temizlik alışkanlıkları salgın öncesi zamana göre ne yönde değişti?” sorusuna verilen cevaplar ile çocuğun cinsiyeti arasında anlamlı bir bağıntı yoktur.

* "Çocuğun temizlik alışkanlıkları salgın öncesi zamana göre ne yönde değişti?" sorusuna verilen cevaplar ile çocuğun gittiği okul arasında .01 düzeyinde anlamlı bir bağıntı vardır. Yüzdelik değerlere bakıldığında, devlet okuluna giden çocukların ebeveynlerinin toplam \%63,1'i biraz ve çok olumlu yönde değişiklik olduğu görüşündedir. Toplam \%10,1’i ise biraz ya da çok olumsuz yönde değişiklik olduğu yönünde görüş bildirmiştir. \%26,8'i ise bir değişiklik olmadığını belirtmiştir. Özel okula giden çocukların ebeveynlerinin ise toplam \%47,1'i biraz ya da çok olumlu yönde değişiklik oldu derken, toplam \%13,5’i biraz ya da çok olumsuz yönde değişiklik oldu demiştir. Değişiklik olmadığını söyleyenlerin oranı ise \%39,3’tür. Bu sonuçlara göre, genel olarak çocukların temizlik alışkanlıklarında olumlu yönde bir değişiklik olduğu anlaşılmaktadır. Devlet okuluna devam eden çocukların temizlik alışkanlıklarının özel okula devam eden çocukların temizlik alışkanlıklarından daha olumlu yönde bir gelişim gösterdiği söylenebilir.

* "Çocuğun temizlik alışkanlıkları salgın öncesi zamana göre ne yönde değişti?" sorusuna verilen cevaplar ile çocuğun devam ettiği öğretim kademesi arasında .01 düzeyinde anlamlı bir bağıntı vardır. Yüzdelik değerlere bakıldığında, ilkokula giden çocukların ebeveynlerinin toplam \%63,4’ü biraz ve çok olumlu yönde değişiklik olduğu görüşündedir. Toplam \%8'i ise biraz ya da çok olumsuz yönde değişiklik olduğu yönünde görüş bildirmiştir. \%29,6’sı ise bir değişiklik olmadığını belirtmiştir. Ortaokula giden çocukların ebeveynlerinin ise toplam \%46,7'si biraz ya da çok olumlu yönde değişiklik oldu derken, toplam \%16,5’i biraz ya da çok olumsuz yönde değişiklik oldu demiştir. Ebeveynlerin \%36,7’si ise değişiklik olmadığını ifade etmiştir. Elde edilen sonuçlara göre, hem ilkokul hem de ortaokula devam eden çocukların temizlik alışkanlıklarında daha çok olumlu yönde bir gelişme olduğu söylenebilir. Olumlu yöndeki değişimin, ilkokula devam eden çocuklarda daha fazla olduğu anlaşılmaktadır. Olumsuz yönde değişim ise daha çok ortaokula devam eden çocuklarda görülmüştür. 


\section{Salgın sürecinin çocukların duygudurumlarına etkileri ile ilgili bulgular}

Covid 19 salgın sürecinin çocukların duygudurumlarına etkileri ile ilgili ebeveynlerin görüşleri aşağıdaki gibidir:

Tablo 5a ve 5b, "Çocuğun kaygı düzeyi salgın öncesi zamana göre ne yönde değişti?” sorusuna verilen cevaplar ile ilgili bulguları göstermektedir.

Tablo 5a: Çocuğun kaygı düzeyi salgın öncesi zamana göre ne yönde değişti?

\begin{tabular}{|l|c|c|}
\hline & f & $\%$ \\
\hline Çok artt1 & 145 & 16,6 \\
Biraz artt1 & 456 & 52,1 \\
\hline Aynı kald1 & 248 & 28,3 \\
Biraz azald1 & 18 & 2,1 \\
Çok azald1 & 9 & 1,0 \\
\hline Toplam & 876 & 100,0 \\
\hline
\end{tabular}

Tablo 5a’ya göre, çocukların kaygı düzeyleri salgın öncesine göre çok arttı ve biraz arttı diyen ebeveynlerin toplam oranı \%68,7 iken biraz azaldı ve çok azaldı diyenlerin toplam oranı \%3,1'dir. Aynı kaldığını söyleyenlerin oranı ise \%28,3'tür. Genel olarak değerlendirildiğinde, çocukların kaygı düzeylerinin salgın öncesi zamana göre arttı̆̆ anlaşılmaktadır.

Tablo 5b: "Çocuğun kaygı düzeyi salgın öncesi zamana göre ne yönde değişti?" sorusuna verilen cevapların çocuğun cinsiyeti, gittiği okul türü ve öğretim kademesi ile ilişkisi

\begin{tabular}{|c|c|c|c|c|c|c|c|c|c|c|c|}
\hline & & & $\frac{\mathscr{O}}{\mathrm{O}} \bar{E}$ & 营 & 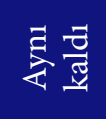 & 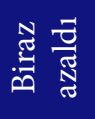 & 응 흘 & $\frac{\Xi}{\tilde{\Xi}}$ & $\chi$ & $\mathrm{sd}$ & $\mathrm{p}$ \\
\hline \multirow{6}{*}{ 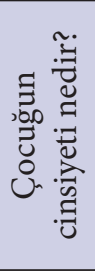 } & \multirow{2}{*}{ K } & $\mathrm{n}$ & 82 & 223 & 112 & 9 & 7 & 433 & \multirow{6}{*}{$7,696 a$} & \multirow{6}{*}{4} & \multirow{6}{*}{,103 } \\
\hline & & $\%$ & $18,9 \%$ & $51,5 \%$ & $25,9 \%$ & $2,1 \%$ & $1,6 \%$ & $100,0 \%$ & & & \\
\hline & \multirow{2}{*}{$\mathrm{E}$} & $\mathrm{n}$ & 63 & 233 & 136 & 9 & 2 & 443 & & & \\
\hline & & $\%$ & $14,2 \%$ & $52,6 \%$ & $30,7 \%$ & $2,0 \%$ &, $5 \%$ & $100,0 \%$ & & & \\
\hline & \multirow{2}{*}{ Toplam } & $\mathrm{n}$ & 145 & 456 & 248 & 18 & 9 & 876 & & & \\
\hline & & $\%$ & $16,6 \%$ & $52,1 \%$ & $28,3 \%$ & $2,1 \%$ & $1,0 \%$ & $100,0 \%$ & & & \\
\hline \multirow{6}{*}{ 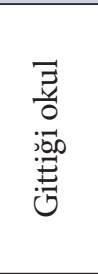 } & \multirow{2}{*}{$\begin{array}{c}\text { Devlet } \\
\text { okulu }\end{array}$} & $\mathrm{n}$ & 99 & 260 & 137 & 12 & 7 & 515 & \multirow{6}{*}{$9,066 \mathrm{a}$} & \multirow{6}{*}{4} & \multirow{6}{*}{, 059} \\
\hline & & $\%$ & $19,2 \%$ & $50,5 \%$ & $26,6 \%$ & $2,3 \%$ & $1,4 \%$ & $100,0 \%$ & & & \\
\hline & \multirow{2}{*}{$\begin{array}{l}\text { Özel } \\
\text { okul }\end{array}$} & $\mathrm{n}$ & 46 & 196 & 111 & 6 & 2 & 361 & & & \\
\hline & & $\%$ & $12,7 \%$ & $54,3 \%$ & $30,7 \%$ & $1,7 \%$ &, $6 \%$ & $100,0 \%$ & & & \\
\hline & \multirow{2}{*}{ Toplam } & $\mathrm{n}$ & 145 & 456 & 248 & 18 & 9 & 876 & & & \\
\hline & & $\%$ & $16,6 \%$ & $52,1 \%$ & $28,3 \%$ & $2,1 \%$ & $1,0 \%$ & $100,0 \%$ & & & \\
\hline \multirow{6}{*}{ 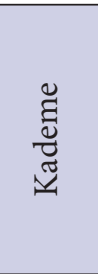 } & \multirow{2}{*}{ İlkokul } & $\mathrm{n}$ & 83 & 276 & 140 & 10 & 5 & 514 & \multirow{6}{*}{$1,381 \mathrm{a}$} & \multirow{6}{*}{4} & \multirow{6}{*}{, 847} \\
\hline & & $\%$ & $16,1 \%$ & $53,7 \%$ & $27,2 \%$ & $1,9 \%$ & $1,0 \%$ & $100,0 \%$ & & & \\
\hline & \multirow{2}{*}{ Ortaokul } & $\mathrm{n}$ & 62 & 180 & 108 & 8 & 4 & 362 & & & \\
\hline & & $\%$ & $17,1 \%$ & $49,7 \%$ & $29,8 \%$ & $2,2 \%$ & $1,1 \%$ & $100,0 \%$ & & & \\
\hline & \multirow{2}{*}{ Toplam } & $\mathrm{n}$ & 145 & 456 & 248 & 18 & 9 & 876 & & & \\
\hline & & $\%$ & $16,6 \%$ & $52,1 \%$ & $28,3 \%$ & $2,1 \%$ & $1,0 \%$ & $100,0 \%$ & & & \\
\hline
\end{tabular}

Tablo 5b, "Çocuğun kaygı düzeyleri salgın öncesi zamana göre ne yönde değişti?" sorusuna verilen cevapların çocuğun cinsiyetine, gittiği okul türüne ve öğretim kademesine göre farklılaşma durumunu ortaya koymaktadır. Elde edilen sonuçlara göre, çocukların kaygı düzeyleri ile cinsiyet, okul türü ve öğretim kademesi arasında anlamlı bir bağıntı yoktur.

Tablo 6a ve 6b, “Çocuğun öfke düzeyi salgın öncesi zamana göre ne yönde değişti?” sorusuna verilen cevaplar ile ilgili bulguları göstermektedir. 
Tablo 6a: Çocuğun öfke düzeyi salgın öncesi zamana göre ne yönde değişti?

\begin{tabular}{l|c|c}
\hline & f & $\%$ \\
\hline Çok arttı & 139 & 15,9 \\
\hline Biraz arttı & 389 & 44,4 \\
\hline Aynı kaldı & 321 & 36,6 \\
\hline Biraz azaldı & 15 & 1,7 \\
Çok azaldı & 12 & 1,4 \\
Toplam & 876 & 100,0 \\
\hline
\end{tabular}

Tablo 6’ya göre, çocukların öfke düzeyleri salgın öncesine göre çok arttı ve biraz arttı diyen ebeveynlerin toplam oranı \%60,3 iken biraz azaldı ve çok azaldı diyenlerin toplam oranı \%3,1'dir. Aynı kaldığını söyleyenlerin oranı ise \%36,6'dır. Elde edilen sonuç genel olarak değerlendirilirse, çocukların öfke düzeylerinin salgın öncesi zamana göre daha çok arttı̆̆ı söylenebilir.

Tablo 6b: “Çocuğun öfke düzeyi salgın öncesi zamana göre ne yönde değişti?” sorusuna verilen cevapların çocuğun cinsiyeti, gittiği okul türü ve öğretim kademesi ile ilişkisi

\begin{tabular}{|c|c|c|c|c|c|c|c|c|c|c|c|}
\hline & & & 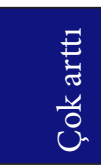 & 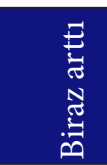 & $\frac{\overline{\vec{\sigma}}}{\frac{\vec{T}}{\bar{y}}}$ & 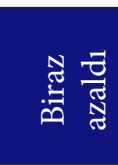 & Uू 즐 & 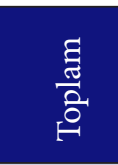 & $\chi$ & sd & $\mathrm{p}$ \\
\hline \multirow{6}{*}{ 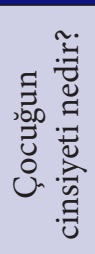 } & \multirow{2}{*}{$\mathrm{K}$} & $\mathrm{n}$ & 60 & 207 & 153 & 7 & 6 & 433 & \multirow{6}{*}{$4,858 \mathrm{a}$} & \multirow{6}{*}{4} & \multirow{6}{*}{,302 } \\
\hline & & $\%$ & $13,9 \%$ & $47,8 \%$ & $35,3 \%$ & $1,6 \%$ & $1,4 \%$ & $100,0 \%$ & & & \\
\hline & \multirow[b]{2}{*}{ E } & $\mathrm{n}$ & 79 & 182 & 168 & 8 & 6 & 443 & & & \\
\hline & & $\%$ & $17,8 \%$ & $41,1 \%$ & $37,9 \%$ & $1,8 \%$ & $1,4 \%$ & $100,0 \%$ & & & \\
\hline & \multirow{2}{*}{ Toplam } & $\mathrm{n}$ & 139 & 389 & 321 & 15 & 12 & 876 & & & \\
\hline & & $\%$ & $15,9 \%$ & $44,4 \%$ & $36,6 \%$ & $1,7 \%$ & $1,4 \%$ & $100,0 \%$ & & & \\
\hline \multirow{6}{*}{ 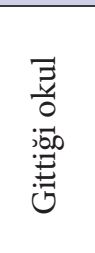 } & \multirow{2}{*}{$\begin{array}{c}\text { Devlet } \\
\text { okulu }\end{array}$} & $\mathrm{n}$ & 86 & 229 & 179 & 11 & 10 & 515 & \multirow{6}{*}{$6,052 a$} & \multirow{6}{*}{4} & \multirow{6}{*}{,195 } \\
\hline & & $\%$ & $16,7 \%$ & $44,5 \%$ & $34,8 \%$ & $2,1 \%$ & $1,9 \%$ & $100,0 \%$ & & & \\
\hline & \multirow{2}{*}{ Özel okul } & $\mathrm{n}$ & 53 & 160 & 142 & 4 & 2 & 361 & & & \\
\hline & & $\%$ & $14,7 \%$ & $44,3 \%$ & $39,3 \%$ & $1,1 \%$ &, $6 \%$ & $100,0 \%$ & & & \\
\hline & \multirow{2}{*}{ Toplam } & $\mathrm{n}$ & 139 & 389 & 321 & 15 & 12 & 876 & & & \\
\hline & & $\%$ & $15,9 \%$ & $44,4 \%$ & $36,6 \%$ & $1,7 \%$ & $1,4 \%$ & $100,0 \%$ & & & \\
\hline \multirow{6}{*}{ 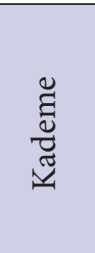 } & \multirow{2}{*}{ İlkokul } & $\mathrm{n}$ & 83 & 229 & 183 & 10 & 9 & 514 & \multirow{6}{*}{$2,149 a$} & \multirow{6}{*}{4} & \multirow{6}{*}{,708 } \\
\hline & & $\%$ & $16,1 \%$ & $44,6 \%$ & $35,6 \%$ & $1,9 \%$ & $1,8 \%$ & $100,0 \%$ & & & \\
\hline & \multirow{2}{*}{ Ortaokul } & $\mathrm{n}$ & 56 & 160 & 138 & 5 & 3 & 362 & & & \\
\hline & & $\%$ & $15,5 \%$ & $44,2 \%$ & $38,1 \%$ & $1,4 \%$ &, $8 \%$ & $100,0 \%$ & & & \\
\hline & \multirow{2}{*}{ Toplam } & $\mathrm{n}$ & 139 & 389 & 321 & 15 & 12 & 876 & & & \\
\hline & & $\%$ & $15,9 \%$ & $44,4 \%$ & $36,6 \%$ & $1,7 \%$ & $1,4 \%$ & $100,0 \%$ & & & \\
\hline
\end{tabular}

Tablo 6b, “Çocuğun öfke düzeyleri salgın öncesi zamana göre ne yönde değişti?” sorusuna verilen cevapların çocuğun cinsiyeti, gittiği okul türü ve öğretim kademesi arasında anlamlı bir bağıntı olmadığını ortaya koymaktadır.

Tablo 7a ve 7b, “Çocuğun korku düzeyi salgın öncesi zamana göre ne yönde değişti?” sorusuna verilen cevaplar ile ilgili bulguları göstermektedir.

Tablo 7a: Çocuğun korku düzeyi salgın öncesi zamana göre ne yönde değişti?

\begin{tabular}{l|c|c|}
\hline & f & $\%$ \\
Çok artt1 & 89 & 10,2 \\
Biraz arttı & 410 & 46,8 \\
Aynı kald1 & 352 & 40,2 \\
Biraz azald1 & 18 & 2,1 \\
Çok azald1 & 7 &, 8 \\
Toplam & 876 & 100,0 \\
\hline
\end{tabular}

Tablo 7a’ya göre, çocukların korku düzeyleri salgın öncesine göre çok arttı ve biraz arttı diyen ebeveynlerin toplam oranı \%57,0 iken biraz azaldı ve çok azaldı diyenlerin toplam oranı \%2,9'dur. Aynı kaldığını söyleyenlerin oranı ise \%40,2'dir. Genel olarak bakıldığında, çocukların korku düzeylerinin salgın öncesine göre daha çok arttı̆̆ı söylenebilir. 
Tablo 7b: “Çocuğun korku düzeyi salgın öncesi zamana göre ne yönde değişti?” sorusuna verilen cevapların çocuğun cinsiyeti, gittiği okul türü ve öğretim kademesi ile ilişkisi

\begin{tabular}{|c|c|c|c|c|c|c|c|c|c|c|c|}
\hline & & & 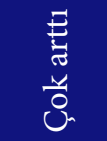 & 胥 & 胥疋 & 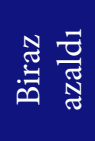 & 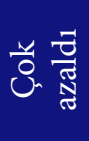 & $\frac{\text { घี }}{\frac{\text { ă }}{0}}$ & $\chi$ & $\mathrm{sd}$ & $\mathrm{p}$ \\
\hline \multirow{6}{*}{ 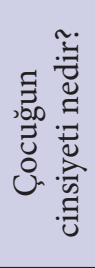 } & \multirow{2}{*}{ K } & $\mathrm{n}$ & 46 & 214 & 162 & 7 & 4 & 433 & \multirow{6}{*}{$4,037 \mathrm{a}$} & \multirow{6}{*}{4} & \multirow{6}{*}{,401 } \\
\hline & & $\%$ & $10,6 \%$ & $49,4 \%$ & $37,4 \%$ & $1,6 \%$ & ,9\% & $100,0 \%$ & & & \\
\hline & \multirow{2}{*}{$\mathrm{E}$} & $\mathrm{n}$ & 43 & 196 & 190 & 11 & 3 & 443 & & & \\
\hline & & $\%$ & $9,7 \%$ & $44,2 \%$ & $42,9 \%$ & $2,5 \%$ &, $7 \%$ & $100,0 \%$ & & & \\
\hline & \multirow{2}{*}{ Toplam } & $\mathrm{n}$ & 89 & 410 & 352 & 18 & 7 & 876 & & & \\
\hline & & $\%$ & $10,2 \%$ & $46,8 \%$ & $40,2 \%$ & $2,1 \%$ &, $8 \%$ & $100,0 \%$ & & & \\
\hline \multirow{6}{*}{ 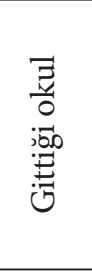 } & \multirow{2}{*}{$\begin{array}{c}\text { Devlet } \\
\text { okulu }\end{array}$} & $\mathrm{n}$ & 63 & 242 & 191 & 14 & 5 & 515 & \multirow{6}{*}{$11,416 a$} & \multirow{6}{*}{4} & \multirow{6}{*}{,022 } \\
\hline & & $\%$ & $12,2 \%$ & $47,0 \%$ & $37,1 \%$ & $2,7 \%$ & $1,0 \%$ & $100,0 \%$ & & & \\
\hline & \multirow{2}{*}{$\begin{array}{l}\text { Özel } \\
\text { okul }\end{array}$} & $\mathrm{n}$ & 26 & 168 & 161 & 4 & 2 & 361 & & & \\
\hline & & $\%$ & $7,2 \%$ & $46,5 \%$ & $44,6 \%$ & $1,1 \%$ &, $6 \%$ & $100,0 \%$ & & & \\
\hline & \multirow{2}{*}{ Toplam } & $\mathrm{n}$ & 89 & 410 & 352 & 18 & 7 & 876 & & & \\
\hline & & $\%$ & $10,2 \%$ & $46,8 \%$ & $40,2 \%$ & $2,1 \%$ &, $8 \%$ & $100,0 \%$ & & & \\
\hline \multirow{6}{*}{ 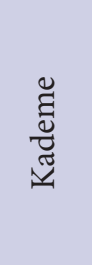 } & \multirow{2}{*}{ İlkokul } & $\mathrm{n}$ & 55 & 251 & 193 & 11 & 4 & 514 & \multirow{6}{*}{$3,650 \mathrm{a}$} & \multirow{6}{*}{4} & \multirow{6}{*}{,455 } \\
\hline & & $\%$ & $10,7 \%$ & $48,8 \%$ & $37,5 \%$ & $2,1 \%$ &, $8 \%$ & $100,0 \%$ & & & \\
\hline & \multirow{2}{*}{ Ortaokul } & $\mathrm{n}$ & 34 & 159 & 159 & 7 & 3 & 362 & & & \\
\hline & & $\%$ & $9,4 \%$ & $43,9 \%$ & $43,9 \%$ & $1,9 \%$ &, $8 \%$ & $100,0 \%$ & & & \\
\hline & \multirow{2}{*}{ Toplam } & $\mathrm{n}$ & 89 & 410 & 352 & 18 & 7 & 876 & & & \\
\hline & & $\%$ & $10,2 \%$ & $46,8 \%$ & $40,2 \%$ & $2,1 \%$ &, $8 \%$ & $100,0 \%$ & & & \\
\hline
\end{tabular}

Tablo 7b, "Çocuğun korku düzeyi salgın öncesi zamana göre ne yönde değişti?” sorusuna verilen cevapların çocuğun cinsiyetine, gittiği okul türüne ve öğretim kademesine göre farklılaşma durumunu ortaya koymaktadır. Elde edilen bulgular şöyledir:

* “Çocuğun korku düzeyi salgın öncesi zamana göre ne yönde değişti?” sorusuna verilen cevaplar ile çocuğun cinsiyeti arasında anlamlı bir bağıntı yoktur.

* “Çocuğun korku düzeyi salgın öncesi zamana göre ne yönde değişti?” sorusuna verilen cevaplar ile çocuğun gittiği okul arasında .05 düzeyinde anlamlı bir bağıntı vardır. Yüzdelik değerlere göre, devlet okuluna giden çocukların ebeveynlerinin toplam \%59,2'si biraz ve çok arttı̆̆ 1 görüşündedir. Yine çocuğu devlet okuluna giden ebeveynlerin toplam \%3,7'si biraz ya da çok azaldığı yönünde görüş bildirmiştir. \%37,1'i ise bir değişiklik olmadığını belirtmiştir. Özel okula giden çocukların ebeveynlerinin ise toplam \%53,7'si biraz ya da çok arttığı yönünde görüş bildirirken, toplam \%1,7'si biraz ya da çok azaldığı yönünde görüş bildirmiştir. Değişiklik olmadığını söyleyenlerin oranı ise \%44,6'dır. Bu sonuçlara göre, hem devlet okuluna giden hem de özel okula giden çocukların korku düzeylerinin salgın öncesine göre artmış olduğu görülmekle birlikte, devlet okulu ebeveynleri, özel okul ebeveynlerine göre daha fazla korkunun arttığını söylemiştir. Yine korkunun azaldığını söyleyenler de daha çok devlet okulu ebeveynleri olmuştur.

* "Çocuğun korku düzeylerinin salgın öncesi zamana göre ne yönde değişti?" sorusuna verilen cevaplar ile çocuğun devam ettiği öğretim kademesi arasında anlamlı bir bağıntı yoktur.

Tablo 8a ve 8b, “Çocuğun mutluluk (neşe) düzeyi salgın öncesi zamana göre ne yönde değişti?” sorusuna verilen cevaplar ile ilgili bulguları göstermektedir.

Tablo 8a: Çocuğun mutluluk (neşe) düzeyi salgın öncesi zamana göre ne yönde değişti?

\begin{tabular}{|l|c|c|}
\hline \multicolumn{1}{|c|}{} & f & $\%$ \\
\hline Çok arttı & 18 & 2,1 \\
Biraz arttı & 71 & 8,1 \\
\hline Aynı kaldı & 339 & 38,7 \\
Biraz azaldı & 361 & 41,2 \\
Çok azaldı & 87 & 9,9 \\
\hline Toplam & 876 & 100,0 \\
\hline
\end{tabular}


Tablo 8a’ya göre, çocukların mutluluk (neşe) düzeyleri salgın öncesine göre çok arttı ve biraz arttı diyen ebeveynlerin toplam oranı \%10,2 iken biraz azaldı ve çok azaldı diyenlerin toplam oranı \%51,1'dir. Aynı kaldığını söyleyenlerin oranı ise \%38,7'dir. Elde edilen bulgulardan yola çıkılarak, çocukların mutluluk (neşe) düzeylerinin salgın öncesi zamana göre azaldığı söylenebilir.

Tablo 8b: "Çocuğun mutluluk (neşe) düzeyi salgın öncesi zamana göre ne yönde değişti?" sorusuna verilen cevapların çocuğun cinsiyeti, gittiği okul türü ve öğretim kademesi ile ilişkisi

\begin{tabular}{|c|c|c|c|c|c|c|c|c|c|c|c|}
\hline & & & 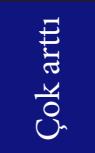 & 氖 & 究 & 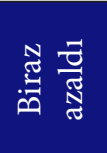 & 응 홇 & $\frac{\text { छ }}{\frac{0}{0}}$ & $\chi$ & sd & $\mathrm{p}$ \\
\hline \multirow{6}{*}{ 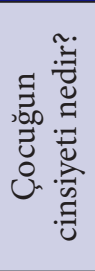 } & \multirow{2}{*}{$\mathrm{K}$} & $\mathrm{n}$ & 7 & 34 & 156 & 186 & 50 & 433 & \multirow{6}{*}{$5,330 \mathrm{a}$} & \multirow{6}{*}{4} & \multirow{6}{*}{,255 } \\
\hline & & $\%$ & $1,6 \%$ & $7,9 \%$ & $36,0 \%$ & $43,0 \%$ & $11,5 \%$ & $100,0 \%$ & & & \\
\hline & \multirow{2}{*}{$\mathrm{E}$} & $\mathrm{n}$ & 11 & 37 & 183 & 175 & 37 & 443 & & & \\
\hline & & $\%$ & $2,5 \%$ & $8,4 \%$ & $41,3 \%$ & $39,5 \%$ & $8,4 \%$ & $100,0 \%$ & & & \\
\hline & \multirow{2}{*}{ Toplam } & $\mathrm{n}$ & 18 & 71 & 339 & 361 & 87 & 876 & & & \\
\hline & & $\%$ & $2,1 \%$ & $8,1 \%$ & $38,7 \%$ & $41,2 \%$ & $9,9 \%$ & $100,0 \%$ & & & \\
\hline \multirow{6}{*}{$\begin{array}{l}\overline{\vec{z}} \\
0 \\
0 \\
: 000 \\
: 0 \\
0\end{array}$} & \multirow{2}{*}{$\begin{array}{l}\text { Devlet } \\
\text { okulu }\end{array}$} & $\mathrm{n}$ & 12 & 44 & 181 & 211 & 67 & 515 & \multirow{6}{*}{$16,775 a$} & \multirow{6}{*}{4} & \multirow{6}{*}{, 002} \\
\hline & & $\%$ & $2,3 \%$ & $8,5 \%$ & $35,1 \%$ & $41,0 \%$ & $13,0 \%$ & $100,0 \%$ & & & \\
\hline & \multirow{2}{*}{$\begin{array}{l}\text { Özel } \\
\text { okul }\end{array}$} & $\mathrm{n}$ & 6 & 27 & 158 & 150 & 20 & 361 & & & \\
\hline & & $\%$ & $1,7 \%$ & $7,5 \%$ & $43,8 \%$ & $41,6 \%$ & $5,5 \%$ & $100,0 \%$ & & & \\
\hline & \multirow{2}{*}{ Toplam } & $\mathrm{n}$ & 18 & 71 & 339 & 361 & 87 & 876 & & & \\
\hline & & $\%$ & $2,1 \%$ & $8,1 \%$ & $38,7 \%$ & $41,2 \%$ & $9,9 \%$ & $100,0 \%$ & & & \\
\hline \multirow{6}{*}{ 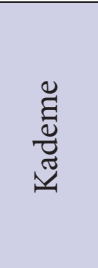 } & \multirow{2}{*}{ İlkokul } & $\mathrm{n}$ & 11 & 50 & 214 & 202 & 37 & 514 & \multirow{6}{*}{$17,311 \mathrm{a}$} & \multirow{6}{*}{4} & \multirow{6}{*}{, 002} \\
\hline & & $\%$ & $2,1 \%$ & $9,7 \%$ & $41,6 \%$ & $39,3 \%$ & $7,2 \%$ & $100,0 \%$ & & & \\
\hline & \multirow{2}{*}{ Ortaokul } & $\mathrm{n}$ & 7 & 21 & 125 & 159 & 50 & 362 & & & \\
\hline & & $\%$ & $1,9 \%$ & $5,8 \%$ & $34,5 \%$ & $43,9 \%$ & $13,8 \%$ & $100,0 \%$ & & & \\
\hline & \multirow{2}{*}{ Toplam } & $\mathrm{n}$ & 18 & 71 & 339 & 361 & 87 & 876 & & & \\
\hline & & $\%$ & $2,1 \%$ & $8,1 \%$ & $38,7 \%$ & $41,2 \%$ & $9,9 \%$ & $100,0 \%$ & & & \\
\hline
\end{tabular}

Tablo 8b, "Çocuğun mutluluk (neşe) düzeyi salgın öncesi zamana göre ne yönde değişti?" sorusuna verilen cevapların çocuğun cinsiyetine, gittiği okul türüne ve öğretim kademesine göre farklılaşma durumunu ortaya koymaktadır. Elde edilen bulgular şöyledir:

* “Çocuğun mutluluk (neşe) düzeyi salgın öncesi zamana göre ne yönde değişti?” sorusuna verilen cevaplar ile çocuğun cinsiyeti arasında anlamlı bir bağıntı yoktur.

* “Çocuğun mutluluk (neşe) düzeyi salgın öncesi zamana göre ne yönde değişti?" sorusuna verilen cevaplar ile çocuğun gittiği okul arasında .01 düzeyinde anlamlı bir bağıntı vardır. Yüzdelik değerler incelendiğinde, devlet okuluna giden çocukların ebeveynlerinin toplam \%10,8'inin biraz ve çok arttığ yönünde görüş bildirdiği; toplam \%54,0’ının biraz ve çok azaldığı yönünde görüş bildirdiği anlaşılmaktadır. Aynı kaldı diyenlerin yüzdesi ise \%35,1'dir. Çocuğu özel okula devam eden ebeveynlerin toplam \%9,3'ü biraz ve çok arttığını ifade etmesine karşın, \%47,1'i ise biraz ve çok azaldığını ifade etmiştir. Aynı kaldığını düşünenler ise \%43,8'dir. Genel olarak değerlendirildiğinde, hem devlet okuluna hem de özel okula giden çocukların ebeveynleri, çocuklarının mutluluk (neşe) düzeylerinin salgın öncesine göre azaldığı yönünde görüş bildirmiştir. Devlet okuluna giden çocukların mutluluğu (neşe) düzeylerinin özel okula giden çocuklara göre daha fazla azaldığı söylenebilir.

* “Çocuğun mutluluk (neşe) düzeylerinin salgın öncesi zamana göre ne yönde değişti?" sorusuna verilen cevaplar ile çocuğun devam ettiği öğretim kademesi arasında .01 düzeyinde anlamlı bir bağıntı vardır. Yüzdelik değerlere göre, ilkokula giden çocukların ebeveynlerinin toplam \%11,8'i çocuklarının mutluluk (neşe) düzeylerinin biraz ve çok arttığını; toplam \%46,9'u ise biraz ve çok azaldığını ifade etmiştir. \%41,6’sı ise aynı kaldığını belirtmiştir. Ortaokula giden çocukların ebeveynlerinin ise toplam \%7,7'si çocuklarının mutluluk (neşe) düzeylerinin biraz ve çok arttığını, toplam \%57,7'si ise biraz ve çok azaldığını ifade etmiştir. Aynı kaldığını ifade ebeveynlerin yüzdesi ise \%34,5'tir. Genel sonuca bakıldığında, hem ilkokula hem de ortaokula devam eden çocukların salgın öncesine göre mutluluk (neşe) düzeylerinin azaldığı söylenebilir. Ortaokula giden çocukların ebeveynleri, ilkokula giden çocukların ebeveynlerine göre çocuklarının mutluluk (neşe) düzeylerinde daha çok azalma 
olduğunu söylemişlerdir. Bun karşın mutluluk (neşe) düzeyleri artanlar ise daha çok ilkokula devam edenler olmuştur.

\section{Salgın sürecinin çocukların sosyal ilişkilerine etkileri ile ilgili bulgular}

Covid 19 salgın sürecinin çocukların sosyal ilişkilerine etkileri ile ilgili ebeveynlerin görüşleri aşağıdaki gibidir:

Tablo 9a ve 9b, “Çocuğun annesiyle ilişkileri salgın öncesi zamana göre ne yönde değişti?” sorusuna verilen cevaplar ile ilgili bulguları göstermektedir.

Tablo 9a: Çocuğun annesiyle ilişkileri salgın öncesi zamana göre ne yönde değişti?

\begin{tabular}{|c|c|c|}
\hline & $\mathrm{f}$ & $\%$ \\
\hline Herhangi bir değişiklik olmadı. & 340 & 38,8 \\
\hline Daha tepkisel davranışlar sergiledi. & 367 & 41,9 \\
\hline Daha içine kapanık oldu, az iletişim kurdu. & 39 & 4,5 \\
\hline Değişken davranışlar sergiledi. & 130 & 14,8 \\
\hline Toplam & 876 & 100,0 \\
\hline
\end{tabular}

Tablo 9a, çocukların annesiyle ilişkilerinin salgın öncesine göre ne yönde değiştiğini göstermektedir. Bulgulara göre, çocukların \%41,9’u annesine karşı daha tepkisel davranmış; \%14,8’i değişken davranışlar sergilemiştir. Daha içine kapanık olup az iletişim kuran çocuklar ise \%4,5’tir. \%38,8’inin davranışlarında herhangi bir değişiklik olmamıştır. Genel olarak değerlendirildiğinde, çocukların çoğunun annesiyle ilişkilerinde salgın öncesine göre daha olumsuz (tepkisel, içine kapanık, az iletişim kurma, değişken davranışlar sergileme vb.) ilişkiler kurduğunu söylemek mümkündür.

Tablo 9b: "Çocuğun annesiyle ilişkileri salgın öncesi zamana göre ne yönde değişti?” sorusuna verilen cevapların çocuğun cinsiyeti, gittiği okul türü ve öğretim kademesi ile ilişkisi

\begin{tabular}{|c|c|c|c|c|c|c|c|c|c|c|}
\hline & & & 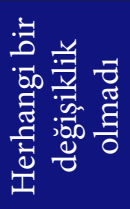 & 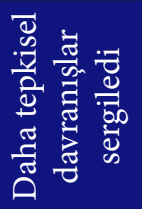 & 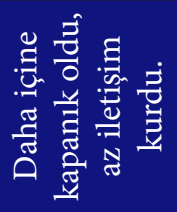 & 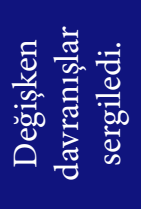 & $\frac{\tilde{\Xi}}{\frac{\mathrm{\sigma}}{0}}$ & $\chi$ & sd & $\mathrm{p}$ \\
\hline \multirow{6}{*}{ 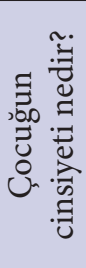 } & \multirow{2}{*}{$\mathrm{K}$} & $\mathrm{n}$ & 170 & 181 & 22 & 60 & 433 & \multirow{6}{*}{$1,364 a$} & \multirow{6}{*}{3} & \multirow{6}{*}{,714 } \\
\hline & & $\%$ & $39,3 \%$ & $41,8 \%$ & $5,1 \%$ & $13,9 \%$ & $100,0 \%$ & & & \\
\hline & \multirow{2}{*}{$\mathrm{E}$} & $\mathrm{n}$ & 170 & 186 & 17 & 70 & 443 & & & \\
\hline & & $\%$ & $38,4 \%$ & $42,0 \%$ & $3,8 \%$ & $15,8 \%$ & $100,0 \%$ & & & \\
\hline & \multirow{2}{*}{ Toplam } & $\mathrm{n}$ & 340 & 367 & 39 & 130 & 876 & & & \\
\hline & & $\%$ & $38,8 \%$ & $41,9 \%$ & $4,5 \%$ & $14,8 \%$ & $100,0 \%$ & & & \\
\hline \multirow{6}{*}{ 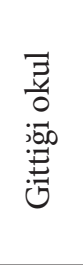 } & \multirow{2}{*}{$\begin{array}{c}\text { Devlet } \\
\text { okulu }\end{array}$} & $\mathrm{n}$ & 216 & 197 & 29 & 73 & 515 & \multirow{6}{*}{$11,385 a$} & \multirow{6}{*}{3} & \multirow{6}{*}{, 010} \\
\hline & & $\%$ & $41,9 \%$ & $38,3 \%$ & $5,6 \%$ & $14,2 \%$ & $100,0 \%$ & & & \\
\hline & \multirow{2}{*}{ Özel okul } & $\mathrm{n}$ & 124 & 170 & 10 & 57 & 361 & & & \\
\hline & & $\%$ & $34,3 \%$ & $47,1 \%$ & $2,8 \%$ & $15,8 \%$ & $100,0 \%$ & & & \\
\hline & \multirow{2}{*}{ Toplam } & $\mathrm{n}$ & 340 & 367 & 39 & 130 & 876 & & & \\
\hline & & $\%$ & $38,8 \%$ & $41,9 \%$ & $4,5 \%$ & $14,8 \%$ & $100,0 \%$ & & & \\
\hline \multirow{6}{*}{ 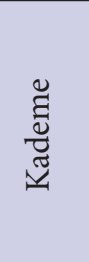 } & \multirow{2}{*}{ İlkokul } & $\mathrm{n}$ & 218 & 220 & 12 & 64 & 514 & \multirow{6}{*}{$21,705 a$} & \multirow{6}{*}{3} & \multirow{6}{*}{, 000} \\
\hline & & $\%$ & $42,4 \%$ & $42,8 \%$ & $2,3 \%$ & $12,5 \%$ & $100,0 \%$ & & & \\
\hline & \multirow{2}{*}{ Ortaokul } & $\mathrm{n}$ & 122 & 147 & 27 & 66 & 362 & & & \\
\hline & & $\%$ & $33,7 \%$ & $40,6 \%$ & $7,5 \%$ & $18,2 \%$ & $100,0 \%$ & & & \\
\hline & \multirow{2}{*}{ Toplam } & $\mathrm{n}$ & 340 & 367 & 39 & 130 & 876 & & & \\
\hline & & $\%$ & $38,8 \%$ & $41,9 \%$ & $4,5 \%$ & $14,8 \%$ & $100,0 \%$ & & & \\
\hline
\end{tabular}

Tablo 9b, “Çocuğun annesiyle ilişkileri salgın öncesi zamana göre ne yönde değişti?” sorusuna verilen cevapların çocuğun cinsiyetine, gittiği okul türüne ve öğretim kademesine göre farklılaşma durumunu ortaya koymaktadır. Elde edilen bulgular şöyledir:

* “Çocuğun annesiyle ilişkileri salgın öncesi zamana göre ne yönde değişti?” sorusuna verilen cevaplar ile çocuğun cinsiyeti arasında anlamlı bir bağıntı yoktur. 
* “Çocuğun annesiyle ilişkileri salgın öncesi zamana göre ne yönde değişti?” sorusuna verilen cevaplar ile çocuğun gittiği okul arasında .01 düzeyinde anlamlı bir bağıntı vardır. Yüzdelik değerler incelendiğinde, devlet okuluna giden çocukların ebeveynlerinin toplam \%41,9'u herhangi bir değişiklik olmadığını söylerken, \%58,1'i olumsuz davranışların (tepkisel, içine kapanık, az iletişim kurma, değişken davranışlar sergileme vb.) arttığını söylemiştir. Özel okula giden çocukların ebeveynlerinin \%34,3’ü herhangi bir değişiklik olmadığını söylerken, \%64,7’si olumsuz davranışların (tepkisel, içine kapanık, az iletişim kurma, değişken davranışlar sergileme vb.) arttığını söylemiştir. Bu sonuçlara göre özel okula devam eden çocukların olumsuz davranışlarının devlet okuluna giden çocukların olumsuz davranışlarına göre daha fazla arttı̆̆ söylenebilir.

* “Çocuğun annesiyle ilişkileri salgın öncesi zamana göre ne yönde değişti?" sorusuna verilen cevaplar ile çocuğun öğretim kademesi arasında .01 düzeyinde anlamlı bir bağıntı vardır. Yüzdelik değerler incelendiğinde, ilkokula devam eden çocukların ebeveynlerinin toplam \%42,4'ü herhangi bir değişiklik olmadığını söylerken, \%57,6'sı olumsuz davranışların (tepkisel, içine kapanık, az iletişim kurma, değiş̧ken davranışlar sergileme vb.) arttı̆̆ını söylemiştir. Ortaokula okula giden çocukların ebeveynlerinin \%33,7’si herhangi bir değişiklik olmadığını söylerken, \%66,3'ü olumsuz davranışların (tepkisel, içine kapanık, az iletişim kurma, değişken davranışlar sergileme vb.) arttığını söylemiştir. Bulgular, ortaokula devam eden çocukların olumsuz davranışlarındaki artışın ilkokula devam eden çocuklardan daha fazla olduğunu ortaya koymaktadır.

Tablo 10a ve 10b, “Çocuğun babasıyla ilişkileri salgın öncesi zamana göre ne yönde değişti??" sorusuna verilen cevaplar ile ilgili bulguları göstermektedir.

Tablo 10a: Çocuğun babasıyla ilişkileri salgın öncesi zamana göre ne yönde değişti?

\begin{tabular}{l|c|c}
\hline \multicolumn{2}{|c|}{ f } & \% \\
\hline Herhangi bir değişiklik olmadı. & 420 & 47,9 \\
Daha tepkisel davranışlar sergiledi. & 266 & 30,4 \\
Daha içine kapanık oldu, az iletişim kurdu. & 51 & 5,8 \\
Değişken davranışlar sergiledi. & 139 & 15,9 \\
Toplam & 876 & 100,0 \\
\hline
\end{tabular}

Tablo 10a, çocukların babasıyla ilişkilerinin salgın öncesine göre ne yönde değiştiğini göstermektedir. Bulgulara göre, çocukların \%30,4'ü babasına karşı daha tepkisel davranmış; \%15,9'u değişken davranışlar sergilemiştir. Daha içine kapanık olup az iletişim kuran çocukların oranı ise \%5,8'dir. \%47,9'unun davranışlarında herhangi bir değişiklik olmamıştır. Genel olarak bakıldığında, salgın sürecinin çocukların babalarıyla olan ilişkilerini dikkati çekecek düzeyde olumsuz yönde (tepkisel, içine kapanık, az iletişim kurma, değişken davranışlar sergileme vb.) etkilediği söylenebilir.

Tablo 10b: "Çocuğun babasıyla ilişkileri salgın öncesi zamana göre ne yönde değişti?” sorusuna verilen cevapların çocuğun cinsiyeti, gittiği okul türü ve öğretim kademesi ile ilişkisi

\begin{tabular}{|c|c|c|c|c|c|c|c|c|c|c|}
\hline & & & 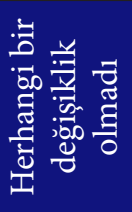 & 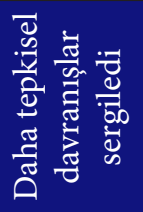 & 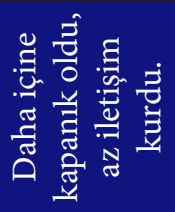 & 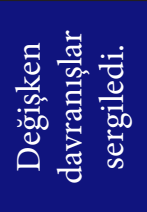 & 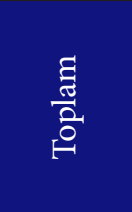 & $\chi$ & sd & $\mathrm{p}$ \\
\hline \multirow{6}{*}{ 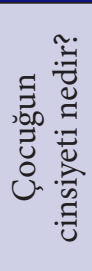 } & \multirow{2}{*}{ K } & $\mathrm{n}$ & 203 & 136 & 29 & 65 & 433 & \multirow{6}{*}{$2,032 \mathrm{a}$} & \multirow{6}{*}{3} & \multirow{6}{*}{,566 } \\
\hline & & $\%$ & $46,9 \%$ & $31,4 \%$ & $6,7 \%$ & $15,0 \%$ & $100,0 \%$ & & & \\
\hline & \multirow{2}{*}{ E } & $\mathrm{n}$ & 217 & 130 & 22 & 74 & 443 & & & \\
\hline & & $\%$ & $49,0 \%$ & $29,3 \%$ & $5,0 \%$ & $16,7 \%$ & $100,0 \%$ & & & \\
\hline & \multirow{2}{*}{ Toplam } & $\mathrm{n}$ & 420 & 266 & 51 & 139 & 876 & & & \\
\hline & & $\%$ & $47,9 \%$ & $30,4 \%$ & $5,8 \%$ & $15,9 \%$ & $100,0 \%$ & & & \\
\hline \multirow{6}{*}{$\begin{array}{l}\vec{\Xi} \\
\text { 吾 } \\
\text { 苛 } \\
\stackrel{\Xi}{0} \\
0\end{array}$} & \multirow{2}{*}{$\begin{array}{c}\text { Devlet } \\
\text { okulu }\end{array}$} & $\mathrm{n}$ & 269 & 133 & 35 & 78 & 515 & \multirow{6}{*}{$15,723 a$} & \multirow{6}{*}{3} & \multirow{6}{*}{,001 } \\
\hline & & $\%$ & $52,2 \%$ & $25,8 \%$ & $6,8 \%$ & $15,1 \%$ & $100,0 \%$ & & & \\
\hline & \multirow{2}{*}{ Özel okul } & $\mathrm{n}$ & 151 & 133 & 16 & 61 & 361 & & & \\
\hline & & $\%$ & $41,8 \%$ & $36,8 \%$ & $4,4 \%$ & $16,9 \%$ & $100,0 \%$ & & & \\
\hline & \multirow{2}{*}{ Toplam } & $\mathrm{n}$ & 420 & 266 & 51 & 139 & 876 & & & \\
\hline & & $\%$ & $47,9 \%$ & $30,4 \%$ & $5,8 \%$ & $15,9 \%$ & $100,0 \%$ & & & \\
\hline
\end{tabular}


Temel Eğitim Araştırmaları Dergisi, 2021; I (2): 163-195 (e-ISSN 2791-6391); DO1: 10.29228/tead.ıl

\begin{tabular}{|c|c|c|c|c|c|c|c|c|c|c|}
\hline \multirow{6}{*}{ 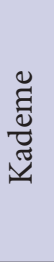 } & \multirow{2}{*}{ İlkokul } & $\mathrm{n}$ & 263 & 156 & 23 & 72 & 514 & \multirow{6}{*}{$9,282 a$} & \multirow{6}{*}{3} & \multirow{6}{*}{,026 } \\
\hline & & $\%$ & $51,2 \%$ & $30,4 \%$ & $4,5 \%$ & $14,0 \%$ & $100,0 \%$ & & & \\
\hline & \multirow{2}{*}{ Ortaokul } & $\mathrm{n}$ & 157 & 110 & 28 & 67 & 362 & & & \\
\hline & & $\%$ & $43,4 \%$ & $30,4 \%$ & $7,7 \%$ & $18,5 \%$ & $100,0 \%$ & & & \\
\hline & \multirow{2}{*}{ Toplam } & $\mathrm{n}$ & 420 & 266 & 51 & 139 & 876 & & & \\
\hline & & $\%$ & $47,9 \%$ & $30,4 \%$ & $5,8 \%$ & $15,9 \%$ & $100,0 \%$ & & & \\
\hline
\end{tabular}

Tablo 10b, "Çocuğun babasıyla ilişkileri salgın öncesi zamana göre ne yönde değişti?” sorusuna verilen cevapların çocuğun cinsiyetine, gittiği okul türüne ve öğretim kademesine göre farklılaşma durumunu ortaya koymaktadır. Elde edilen bulgular şöyledir:

* "Çocuğun babasıyla ilişkileri salgın öncesi zamana göre ne yönde değişti?" sorusuna verilen cevaplar ile çocuğun cinsiyeti arasında anlamlı bir bağıntı yoktur.

* “Çocuğun babasıyla ilişkileri salgın öncesi zamana göre ne yönde değişti?" sorusuna verilen cevaplar ile çocuğun gittiği okul arasında .01 düzeyinde anlamlı bir bağıntı vardır. Yüzdelik değerler incelendiğinde, devlet okuluna giden çocukların ebeveynlerinin toplam \%52,2'si herhangi bir değişiklik olmadığını söylerken, \%58,1'i olumsuz davranışların (tepkisel, içine kapanık, az iletișim kurma, değişken davranıșlar sergileme vb.) arttığını söylemiştir. Özel okula giden çocukların ebeveynlerinin \%34,3'ü herhangi bir değişiklik olmadığını söylerken, \%64,7'si olumsuz davranışların (tepkisel, içine kapanık, az iletişim kurma, değişken davranışlar sergileme vb.) arttığını söylemiştir. Bu sonuçlara göre özel okula devam eden çocukların olumsuz davranışlarının devlet okuluna giden çocukların olumsuz davranışlarına göre daha fazla arttı̆̆ı söylenebilir.

* "Çocuğun annesiyle ilişkileri salgın öncesi zamana göre ne yönde değişti?" sorusuna verilen cevaplar ile çocuğun öğretim kademesi arasında .01 düzeyinde anlamlı bir bağıntı vardır. Yüzdelik değerler incelendiğinde, ilkokula devam eden çocukların ebeveynlerinin toplam \%42,4'ü herhangi bir değişiklik olmadı̆̆ını söylerken, \%57,6'sı olumsuz davranışların (tepkisel, içine kapanık, az iletişim kurma, değişken davranışlar sergileme vb.) arttığını söylemiştir. Ortaokula okula giden çocukların ebeveynlerinin \%33,7'si herhangi bir değişiklik olmadığını söylerken, \%66,3’ü olumsuz davranışların (tepkisel, içine kapanık, az iletişim kurma, değişken davranışlar sergileme vb.) arttığını söylemiştir. Bulgular, ortaokula devam eden çocukların olumsuz davranışlarındaki artışın ilkokula devam eden çocuklardan daha fazla olduğunu ortaya koymaktadır.

Tablo 11a ve 11b, “Çocuğun (varsa) kardeş(ler)iyle ilişkileri salgın öncesi zamana göre ne yönde değişti?” sorusuna verilen cevaplar ile ilgili bulguları göstermektedir.

Tablo 11a: Çocuğun (varsa) kardeş(ler)iyle ilişkileri salgın öncesi zamana göre ne yönde değişti?

\begin{tabular}{l|c|c|}
\hline & f & $\%$ \\
\hline Herhangi bir değişiklik olmadı. & 521 & 59,5 \\
\hline Daha tepkisel davranışlar sergiledi. & 216 & 24,7 \\
Daha içine kapanık oldu, az iletişim kurdu. & 17 & 1,9 \\
Değişken davranışlar sergiledi. & 122 & 13,9 \\
\hline Toplam & 876 & 100,0 \\
\hline
\end{tabular}

Tablo 11a, çocukların kardeş(ler)iyle ilişkilerinin salgın öncesine göre ne yönde değiştiğini göstermektedir. Bulgulara göre, çocukların \%24,7'si kardeş(ler)ine karşı daha tepkisel davranmış; \%13,9’u değişken davranışlar sergilemiştir. Daha içine kapanık olup az iletişim kuran çocuklar ise \%1,9'dur. \%59,5’inin davranışlarında herhangi bir değişiklik olmamıştır. Genel sonuca bakıldığında, salgın sürecinin çocukların kardeş(ler)iyle ilişkilerini dikkati çekecek düzeyde olumsuz yönde (tepkisel, içine kapanık, az iletişim kurma, değişken davranışlar sergileme vb.) etkilediği söylenebilir. 
Tablo 11b: “Çocuğun (varsa) kardeş(ler)iyle ilişkileri salgın öncesi zamana göre ne yönde değişti?” sorusuna verilen cevapların çocuğun cinsiyeti, gittiği okul türü ve öğretim kademesi ile ilişkisi

\begin{tabular}{|c|c|c|c|c|c|c|c|c|c|c|}
\hline & & & 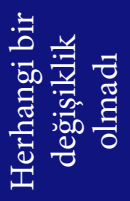 & 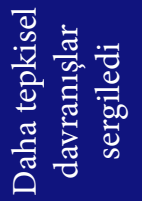 & 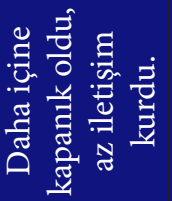 & 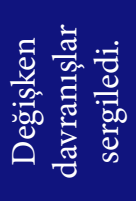 & $\frac{\tilde{\Xi}}{\stackrel{0}{0}}$ & $\chi$ & sd & $p$ \\
\hline \multirow{6}{*}{ 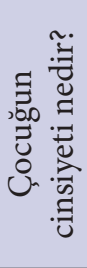 } & \multirow{2}{*}{$\mathrm{K}$} & $\mathrm{n}$ & 240 & 115 & 6 & 72 & 433 & \multirow{6}{*}{$9,459 \mathrm{a}$} & \multirow{6}{*}{3} & \multirow{6}{*}{,024 } \\
\hline & & $\%$ & $55,4 \%$ & $26,6 \%$ & $1,4 \%$ & $16,6 \%$ & $100,0 \%$ & & & \\
\hline & \multirow{2}{*}{ E } & $\mathrm{n}$ & 281 & 101 & 11 & 50 & 443 & & & \\
\hline & & $\%$ & $63,4 \%$ & $22,8 \%$ & $2,5 \%$ & $11,3 \%$ & $100,0 \%$ & & & \\
\hline & \multirow{2}{*}{ Toplam } & $\mathrm{n}$ & 521 & 216 & 17 & 122 & 876 & & & \\
\hline & & $\%$ & $59,5 \%$ & $24,7 \%$ & $1,9 \%$ & $13,9 \%$ & $100,0 \%$ & & & \\
\hline \multirow{6}{*}{ 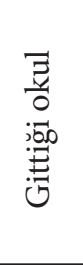 } & \multirow{2}{*}{$\begin{array}{c}\text { Devlet } \\
\text { okulu }\end{array}$} & $\mathrm{n}$ & 272 & 147 & 11 & 85 & 515 & \multirow{6}{*}{$23,181 a$} & \multirow{6}{*}{3} & \multirow{6}{*}{,000 } \\
\hline & & $\%$ & $52,8 \%$ & $28,5 \%$ & $2,1 \%$ & $16,5 \%$ & $100,0 \%$ & & & \\
\hline & \multirow{2}{*}{ Özel okul } & $\mathrm{n}$ & 249 & 69 & 6 & 37 & 361 & & & \\
\hline & & $\%$ & $69,0 \%$ & $19,1 \%$ & $1,7 \%$ & $10,2 \%$ & $100,0 \%$ & & & \\
\hline & \multirow{2}{*}{ Toplam } & $\mathrm{n}$ & 521 & 216 & 17 & 122 & 876 & & & \\
\hline & & $\%$ & $59,5 \%$ & $24,7 \%$ & $1,9 \%$ & $13,9 \%$ & $100,0 \%$ & & & \\
\hline \multirow{6}{*}{ 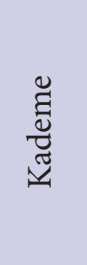 } & \multirow{2}{*}{ İlkokul } & $\mathrm{n}$ & 297 & 136 & 9 & 72 & 514 & \multirow{6}{*}{$2,473 a$} & \multirow{6}{*}{3} & \multirow{6}{*}{,480 } \\
\hline & & $\%$ & $57,8 \%$ & $26,5 \%$ & $1,8 \%$ & $14,0 \%$ & $100,0 \%$ & & & \\
\hline & \multirow{2}{*}{ Ortaokul } & $\mathrm{n}$ & 224 & 80 & 8 & 50 & 362 & & & \\
\hline & & $\%$ & $61,9 \%$ & $22,1 \%$ & $2,2 \%$ & $13,8 \%$ & $100,0 \%$ & & & \\
\hline & \multirow{2}{*}{ Toplam } & $\mathrm{n}$ & 521 & 216 & 17 & 122 & 876 & & & \\
\hline & & $\%$ & $59,5 \%$ & $24,7 \%$ & $1,9 \%$ & $13,9 \%$ & $100,0 \%$ & & & \\
\hline
\end{tabular}

Tablo 11b, "Çocuğun (varsa) kardeş(ler)iyle ilişkileri salgın öncesi zamana göre ne yönde değişti?" sorusuna verilen cevapların çocuğun cinsiyetine, gittiği okul türüne ve öğretim kademesine göre farklılaşma durumunu ortaya koymaktadır. Elde edilen bulgular şöyledir:

* “Çocuğun kardeş(ler)iyle ilişkileri salgın öncesi zamana göre ne yönde değişti?” sorusuna verilen cevaplar ile çocuğun cinsiyeti arasında .05 düzeyinde anlamlı bir bağıntı vardır. Yüzdelik değerlere bakıldığında, kız çocuğu olan ebeveynlerin \%55,4’ü herhangi bir değişiklik olmadığını söylemiş; \%44,6’sı ise olumsuz davranışların (tepkisel, içine kapanık, az iletişim kurma, değişken davranışlar sergileme vb.) arttığını söylemiştir. Erkek çocuğu olan ebeveynlerin ise \%63,4'ü herhangi bir değişiklik olmadığını söylerken, \%36,4’ü ise olumsuz davranışların (tepkisel, içine kapanık, az iletişim kurma, değişken davranışlar sergileme vb.) arttığını söylemiştir. Sonuçlar bir bütün olarak değerlendirildiğinde, kız çocukların olumsuz davranışları erkeklerden daha çok artmış görünmektedir.

* "Çocuğun kardeş(ler)iyle ilişkileri salgın öncesi zamana göre ne yönde değişti?" sorusuna verilen cevaplar ile çocuğun gittiği okul arasında .01 düzeyinde anlamlı bir bağıntı vardır. Yüzdelik değerler incelendiğinde, devlet okuluna giden çocukların ebeveynleri toplam \%52,8’i herhangi bir değişiklik olmadığ görüşündedir. Ebeveynlerin toplam \%47,2'si ise olumsuz yönde (tepkisel, içine kapanık, az iletişim kurma, değişken davranışlar sergileme vb.) değişiklikler yaşadıkları görüşündedirler. Özel okula giden çocukların ebeveynlerinin \%69,0’1 herhangi bir değişiklik olmadığını ifade etmiştir. Yine özel okula giden çocukların ebeveynlerinin toplam \%31,0’1 ise olumsuz değişikler (tepkisel, içine kapanık, az iletişim kurma, değişken davranışlar sergileme vb.) olduğunu belirtmiştir. Bu sonuçlara göre devlet okuluna devam eden çocukların olumsuz davranışlarının özel okula giden çocukların olumsuz davranışlarına göre daha fazla arttığg söylenebilir.

* “Çocuğun kardeş(ler)iyle ilişkileri salgın öncesi zamana göre ne yönde değişti?” sorusuna verilen cevaplar ile çocuğun öğretim kademesi arasında anlamlı bir bağıntı yoktur.

Tablo 12a ve 12b, "Çocuğun öğretmeniyle ilgili algıları salgın öncesi zamana göre ne yönde değişti?” sorusuna verilen cevaplar ile ilgili bulguları göstermektedir. 
Tablo 12a: Çocuğun öğretmeniyle ilgili algıları salgın öncesi zamana göre ne yönde değişti?

\begin{tabular}{l|c|c|}
\hline & f & $\%$ \\
\hline Herhangi bir değişiklik olmadı & 301 & 34,4 \\
\hline Özlediğini/görmek istediğini ifade etti & 486 & 55,5 \\
İlgilenmedi & 89 & 10,2 \\
\hline Toplam & 876 & 100,0 \\
\hline
\end{tabular}

Tablo 12a, çocukların öğretmeniyle ilgili algılarının salgın öncesine göre ne yönde değiştiğini göstermektedir. Ebeveynlerin cevaplarına göre, çocukların \%55,5’i öğretmen(ler)ini özlediğini/görmek istediğini ifade ederken, \%10,2'si öğretmenlerine karşı ilgisiz kalmış, \%34,4'ünde ise öğretmenlerine karşı duygularında herhangi bir değişiklik olmadığını ifade etmiştir. Genel olarak değerlendirildiğinde, çocukların yarıdan fazlasının öğretmenlerini özledikleri görülmektedir.

Tablo 12b: “Çocuğun öğretmeniyle ilgili algıları salgın öncesi zamana göre ne yönde değişti?” sorusuna verilen cevapların çocuğun cinsiyeti, gittiği okul türü ve öğretim kademesi ile ilişkisi

\begin{tabular}{|c|c|c|c|c|c|c|c|c|c|}
\hline & & & 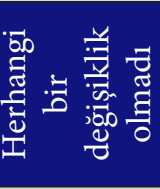 & 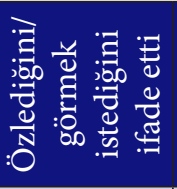 & 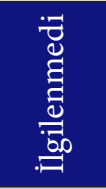 & $\frac{\text { ज्ञ }}{\text { ?ै }}$ & $\chi$ & sd & $\mathrm{p}$ \\
\hline \multirow{6}{*}{ 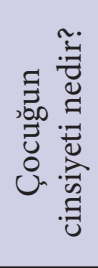 } & \multirow{2}{*}{ K } & $\mathrm{n}$ & 145 & 254 & 34 & 433 & \multirow{6}{*}{$6,240 \mathrm{a}$} & \multirow{6}{*}{2} & \multirow{6}{*}{, 044} \\
\hline & & $\%$ & $33,5 \%$ & $58,7 \%$ & $7,9 \%$ & $100,0 \%$ & & & \\
\hline & \multirow{2}{*}{$\mathrm{E}$} & $\mathrm{n}$ & 156 & 232 & 55 & 443 & & & \\
\hline & & $\%$ & $35,2 \%$ & $52,4 \%$ & $12,4 \%$ & $100,0 \%$ & & & \\
\hline & \multirow{2}{*}{ Toplam } & $\mathrm{n}$ & 301 & 486 & 89 & 876 & & & \\
\hline & & $\%$ & $34,4 \%$ & $55,5 \%$ & $10,2 \%$ & $100,0 \%$ & & & \\
\hline \multirow{6}{*}{ 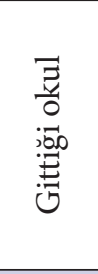 } & \multirow{2}{*}{$\begin{array}{l}\text { Devlet } \\
\text { okulu }\end{array}$} & $\mathrm{n}$ & 179 & 280 & 56 & 515 & \multirow{6}{*}{, $962 \mathrm{a}$} & \multirow{6}{*}{2} & \multirow{6}{*}{,618 } \\
\hline & & $\%$ & $34,8 \%$ & $54,4 \%$ & $10,9 \%$ & $100,0 \%$ & & & \\
\hline & \multirow{2}{*}{ Özel okul } & $\mathrm{n}$ & 122 & 206 & 33 & 361 & & & \\
\hline & & $\%$ & $33,8 \%$ & $57,1 \%$ & $9,1 \%$ & $100,0 \%$ & & & \\
\hline & \multirow{2}{*}{ Toplam } & $\mathrm{n}$ & 301 & 486 & 89 & 876 & & & \\
\hline & & $\%$ & $34,4 \%$ & $55,5 \%$ & $10,2 \%$ & $100,0 \%$ & & & \\
\hline \multirow{6}{*}{ 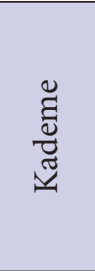 } & \multirow{2}{*}{ İlkokul } & $\mathrm{n}$ & 165 & 316 & 33 & 514 & \multirow{6}{*}{$27,038 \mathrm{a}$} & \multirow{6}{*}{2} & \multirow{6}{*}{, 000} \\
\hline & & $\%$ & $32,1 \%$ & $61,5 \%$ & $6,4 \%$ & $100,0 \%$ & & & \\
\hline & \multirow{2}{*}{ Ortaokul } & $\mathrm{n}$ & 136 & 170 & 56 & 362 & & & \\
\hline & & $\%$ & $37,6 \%$ & $47,0 \%$ & $15,5 \%$ & $100,0 \%$ & & & \\
\hline & \multirow{2}{*}{ Toplam } & $\mathrm{n}$ & 301 & 486 & 89 & 876 & & & \\
\hline & & $\%$ & $34,4 \%$ & $55,5 \%$ & $10,2 \%$ & $100,0 \%$ & & & \\
\hline
\end{tabular}

Tablo 12b, “Çocuğun öğretmenleriyle ilgili algıları ilişkileri salgın öncesi zamana göre ne yönde değişti?” sorusuna verilen cevapların çocuğun cinsiyetine, gittiği okul türüne ve öğretim kademesine göre farklılaşma durumunu ortaya koymaktadır. Elde edilen bulgular şöyledir:

* “Çocuğun öğretmenleriyle ilgili algıları ilişkileri salgın öncesi zamana göre ne yönde değişti?” sorusuna verilen cevaplar ile çocuğun cinsiyeti arasında .05 düzeyinde anlamlı bir bağıntı vardır. Yüzdelik değerlere bakıldığında, kız çocuğu olan ebeveynlerin \%33,5’i herhangi bir değişiklik olmadığını, \%58,7'si özlediğini; \%7,9'u ise ilgilenmediğini ifade etmiştir. Erkek çocuğu olan ebeveynlerin ise \%35,2'si herhangi bir değişiklik olmadığını, \%52,4’ü özlediğini, \%12,4’ü ise ilgilenmediğini ifade etmiştir. Sonuçlar genel olarak ele alındığında, kız çocukların öğretmenlerini erkek çocuklara göre biraz daha fazla özlediği söylenebilir.

* “Çocuğun öğretmenleriyle ilgili algıları ilişkileri salgın öncesi zamana göre ne yönde değişti?” sorusuna verilen cevaplar ile çocuğun gittiği okul arasında anlamlı bir bağıntı bulunamamıştır.

* “Çocuğun öğretmenleriyle ilgili algıları ilişkileri salgın öncesi zamana göre ne yönde değişti?” sorusuna verilen cevaplar ile çocuğun devam ettiği öğretim kademesi arasında .01 düzeyinde anlamlı bir bağıntı bulunmuştur. Yüzdelik değerler incelendiğinde, ebeveyn görüşlerine göre, ilkokula devam eden çocukların \%32,1'inde herhangi bir değişiklik olmamış, \%61,5’i özlemiş, \%6,4’ü ise ilgisiz kalmıştır. Yine ebeveyn görüşlerine göre, 
ortaokula devam eden çocukların \%37,6'sında herhangi bir değişiklik olmamış, \%47,0’ı özlemiş; \%15,5’i ise ilgisiz kalmıştır. Sonuçlara genel olarak bakıldığında, ilkokula devam eden çocukların ortaokula devam eden çocuklara göre öğretmenlerini daha çok özledikleri anlaşılmaktadır.

\section{Salgın sürecinde çocukların uzaktan eğitim ile ilgili davranışları üzerindeki etkileri ile ilgili bulgular}

Covid 19 salgın sürecinde çocukların uzaktan eğitime alışma durumları ile ilgili ebeveynlerin görüşleri aşağıdaki gibidir:

Tablo 13a ve 13b, “Çocuğun uzaktan eğitime alışma düzeyi ne oldu?” sorusuna verilen cevaplar ile ilgili bulguları göstermektedir.

Tablo 13a: Çocuğun uzaktan eğitime alışma düzeyi ne oldu?

\begin{tabular}{l|c|c} 
& f & \% \\
\hline Çok kolay alıştı, herhangi bir sorun yaşamadı & 229 & 26,1 \\
Alıştı ama nadiren de olsa müdahale etmemiz/yönlendirmemiz gerekti & 222 & 25,3 \\
Alıştı ama bazen müdahale etmemiz/yönlendirmemiz gerekti & 197 & 22,5 \\
Alıștı ama sık sık müdahale etmemiz/yönlendirmemiz gerekti & 156 & 17,8 \\
Pek alışamadı & 72 & 8,2 \\
Toplam & 876 & 100,0 \\
\hline
\end{tabular}

Tablo 13a, salgın sürecinde çocukların uzaktan eğitime alışma düzeyi ile ilgili sonuçları göstermektedir. Ebeveynlerin cevaplarına göre, çocukların \%26,1'i uzaktan eğitime çok kolay alışmış ve herhangi bir sorun yaşamamıştır. Alışmış olsa da nadiren, bazen ve sık sık müdahale edilmesi/yönlendirilmesi gereken çocukların toplam oranı \%65,6 olmuştur. Pek alışamayan çocukların oranı ise \%8,2'dir. Sonuçlar bir bütün olarak değerlendirildiğinde, çocukların \%74,9’unun az ya da çok uzaktan eğitime yeterince alışamadığı anlaşılmaktadır.

Tablo 13b: "Çocuğun uzaktan eğitime alışma düzeyi ne oldu?" sorusuna verilen cevapların çocuğun cinsiyeti, gittiği okul türü ve öğretim kademesi ile ilişkisi

\begin{tabular}{|c|c|c|c|c|c|c|c|c|c|c|c|}
\hline & & & 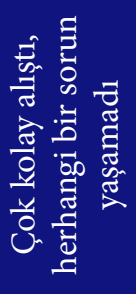 & 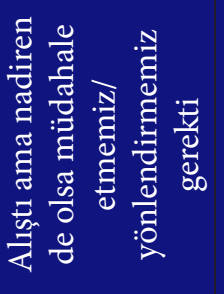 & 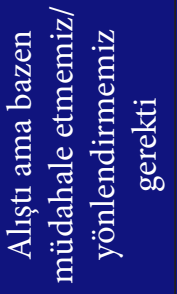 & 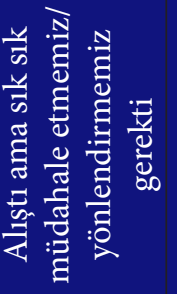 & 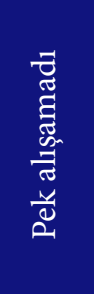 & $\frac{\text { E }}{\frac{0}{0}}$ & $\chi$ & $\mathrm{sd}$ & $\mathrm{p}$ \\
\hline \multirow{6}{*}{ 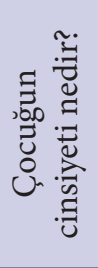 } & \multirow{2}{*}{$\mathrm{K}$} & $\mathrm{n}$ & 128 & 117 & 81 & 75 & 32 & 433 & \multirow{6}{*}{$11,057 \mathrm{a}$} & \multirow{6}{*}{4} & \multirow{6}{*}{,026 } \\
\hline & & $\%$ & $29,6 \%$ & $27,0 \%$ & $18,7 \%$ & $17,3 \%$ & $7,4 \%$ & $100,0 \%$ & & & \\
\hline & \multirow{2}{*}{$\mathrm{E}$} & $\mathrm{n}$ & 101 & 105 & 116 & 81 & 40 & 443 & & & \\
\hline & & $\%$ & $22,8 \%$ & $23,7 \%$ & $26,2 \%$ & $18,3 \%$ & $9,0 \%$ & $100,0 \%$ & & & \\
\hline & \multirow{2}{*}{ Toplam } & $\mathrm{n}$ & 229 & 222 & 197 & 156 & 72 & 876 & & & \\
\hline & & $\%$ & $26,1 \%$ & $25,3 \%$ & $22,5 \%$ & $17,8 \%$ & $8,2 \%$ & $100,0 \%$ & & & \\
\hline \multirow{6}{*}{ 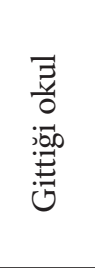 } & \multirow{2}{*}{$\begin{array}{l}\text { Devlet } \\
\text { okulu }\end{array}$} & $\mathrm{n}$ & 135 & 138 & 98 & 93 & 51 & 515 & \multirow{6}{*}{$12,049 a$} & \multirow{6}{*}{4} & \multirow{6}{*}{,017 } \\
\hline & & $\%$ & $26,2 \%$ & $26,8 \%$ & $19,0 \%$ & $18,1 \%$ & $9,9 \%$ & $100,0 \%$ & & & \\
\hline & \multirow{2}{*}{$\begin{array}{l}\text { Özel } \\
\text { okul }\end{array}$} & $\mathrm{n}$ & 94 & 84 & 99 & 63 & 21 & 361 & & & \\
\hline & & $\%$ & $26,0 \%$ & $23,3 \%$ & $27,4 \%$ & $17,5 \%$ & $5,8 \%$ & $100,0 \%$ & & & \\
\hline & \multirow{2}{*}{ Toplam } & $\mathrm{n}$ & 229 & 222 & 197 & 156 & 72 & 876 & & & \\
\hline & & $\%$ & $26,1 \%$ & $25,3 \%$ & $22,5 \%$ & $17,8 \%$ & $8,2 \%$ & $100,0 \%$ & & & \\
\hline \multirow{6}{*}{ 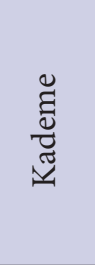 } & \multirow{2}{*}{ İlkokul } & $\mathrm{n}$ & 133 & 144 & 114 & 94 & 29 & 514 & \multirow{6}{*}{$13,806 a$} & \multirow{6}{*}{4} & \multirow{6}{*}{,008 } \\
\hline & & $\%$ & $25,9 \%$ & $28,0 \%$ & $22,2 \%$ & $18,3 \%$ & $5,6 \%$ & $100,0 \%$ & & & \\
\hline & \multirow{2}{*}{ Ortaokul } & $\mathrm{n}$ & 96 & 78 & 83 & 62 & 43 & 362 & & & \\
\hline & & $\%$ & $26,5 \%$ & $21,5 \%$ & $22,9 \%$ & $17,1 \%$ & $11,9 \%$ & $100,0 \%$ & & & \\
\hline & \multirow{2}{*}{ Toplam } & $\mathrm{n}$ & 229 & 222 & 197 & 156 & 72 & 876 & & & \\
\hline & & $\%$ & $26,1 \%$ & $25,3 \%$ & $22,5 \%$ & $17,8 \%$ & $8,2 \%$ & $100,0 \%$ & & & \\
\hline
\end{tabular}


Tablo 13b, "Çocuğun uzaktan eğitime alışma düzeyi ne oldu?" sorusuna verilen cevapların çocuğun cinsiyetine, gittiği okul türüne ve öğretim kademesine göre farklılaşma durumunu ortaya koymaktadır. Elde edilen sonuçlar şöyledir:

* “Çocuğun uzaktan eğitime alışma düzeyi ne oldu?" sorusuna verilen cevaplar ile çocuğun cinsiyeti arasında .05 düzeyinde anlamlı bir bağıntı vardır. Yüzdelik değerlere bakıldığında, ebeveynlerin görüşlerine göre, kız çocuklarının \%29,6'sı çok kolay alıştı ve herhangi bir sorun yaşamadı. Kızların \%70,4'ü ise az ya da çok uzaktan eğitime yeterince alışamadıkları söylenebilir. Yine ebeveyn görüşlerine göre, erkek çocukların \%22,8'i uzaktan eğitime alışmış görünürken; \%77,2'sinin az ya da çok alışma sorunu yaşadıkları söylenebilir. Yüzdelik değerler genel olarak ele alındığında, erkek çocuklarının uzaktan eğitime alışma konusunda kız çocuklarına göre daha fazla zorlandıkları söylenebilir.

* “Çocuğun uzaktan eğitime alışma düzeyi ne oldu?” sorusuna verilen cevaplar ile çocuğun devam ettiği okulun türü arasında .05 düzeyinde anlamlı bir bağıntı vardır. Yüzdelik değerlere bakıldığında, ebeveynlerin görüşlerine göre, devlet okuluna devam eden çocukların \%26,2'si uzaktan eğitime kolay alışmış görünmektedir. Yine devlet okuluna giden çocukların \%73,8'inin az ya da çok alışma sorunları yaşadığı anlaşılmaktadır. Özel okula gidenler açısından durum değerlendirildiğinde, \%26,0’ının uzaktan eğitime alışma sorunu yaşamadığ 1 söylenebilir. Buna karşın \%74,0'ü ise az ya da çok alışma sorunu yaşamış görünmektedir. Devlet okulu ve özel okula devam etme açısından genel sonuca bakıldığında en dikkati çeken sonucun, neredeyse hiç alışamamış olanlarla ilgili olduğu söylenebilir. Devlet okuluna giden çocukların özel okula giden çocuklara göre uzaktan eğitime alışma sorununu daha fazla yaşadıkları söylenebilir.

* “Çocuğun uzaktan eğitime alı̧̧ma düzeyi ne oldu?” sorusuna verilen cevaplar ile çocuğun devam ettiği öğretim kademesi arasında .01 düzeyinde anlamlı bir bağıntı vardır. Yüzdelik değerlere bakıldığında, ilkokula devam eden çocukların ebeveynleri, \%25,9 herhangi bir alışma sorunu yaşamadıklarını söylemiştir. Buna karşın \%74,1'i ise az ya da çok alışma sorunu yaşandığını ifade etmiştir. Ortaokula devam eden çocukların ebeveynleri ise, \%26,5 ile alışma sorunu yaşanmadığını söylerken, $\% 73,5^{\prime} \mathrm{i}$ az ya da çok alışma sorunu yaşadıklarını ifade etmiştir. Her iki grup karşılaştırıldığında, ortaokula devam eden çocukların ebeveynlerinin "pek alışmadı" seçeneğini daha çok işaretledikleri görülmektedir.

Tablo 14a ve 14b, “Çocuğun uzaktan eğitime katılma düzeyi nasıldı?” sorusuna verilen cevaplar ile ilgili bulguları göstermektedir.

Tablo 14a: Çocuğun uzaktan eğitime katılma düzeyi nasıldı?

\begin{tabular}{l|c|c|} 
& f & $\%$ \\
\hline Hiç aksatmadan düzenli olarak katıldı & 582 & 66,4 \\
Çoğunlukla katıldı & 211 & 24,1 \\
Bazen katıldı, bazen katılmadı & 65 & 7,4 \\
Nadiren katıldı & 9 & 1,0 \\
Neredeyse hiç katılmadı & 9 & 1,0 \\
Toplam & 876 & 100,0 \\
\hline
\end{tabular}

Tablo 14a, salgın sürecinde çocukların uzaktan eğitime katılma düzeyi ile ilgili sonuçları göstermektedir. Ebeveynlerin cevaplarına göre, çocukların \%66,4'ü uzaktan eğitime hiç aksatmadan düzenli olarak katılmıştır. Çoğunlukla katılanların oranı \%24,1 olmuştur. Bazen ve nadiren katılanların oranı ise toplam \%8,4'tür. Neredeyse hiç katılmayanların oranı da \%1,0 olarak belirlenmiştir. Sonuçlar genel olarak değerlendirildiğinde, çocukların \%90,5'inin hiç aksatmadan ya da çoğunlukla uzaktan eğitime katıldıkları anlaşılmaktadır. \%9,5'inin ise katılımla ilgili bazı sorunlar yaşadıkları görülmektedir. Bu katılım düzeyinde ebeveynlerin çocukları ile ilgili yönlendirmelerinin ve takiplerinin etkisi olduğu düşünülebilir. 
Tablo 14b: "Çocuğun uzaktan eğitime katılma düzeyi nasıldı?” sorusuna verilen cevapların çocuğun cinsiyeti, gittiği okul türü ve öğretim kademesi ile ilişkisi

\begin{tabular}{|c|c|c|c|c|c|c|c|c|c|c|c|}
\hline & & & 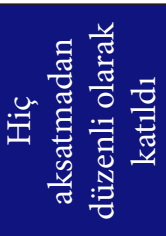 & 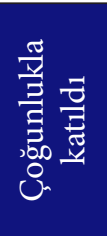 & 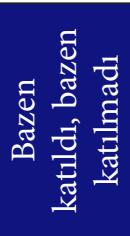 & 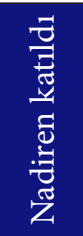 & 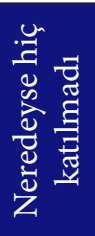 & 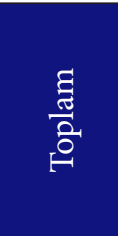 & $\square$ & sd & $\mathrm{p}$ \\
\hline \multirow{6}{*}{ 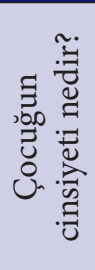 } & \multirow{2}{*}{ K } & $\mathrm{n}$ & 298 & 91 & 36 & 5 & 3 & 433 & \multirow{6}{*}{$6,074 a$} & \multirow{6}{*}{4} & \multirow{6}{*}{,194 } \\
\hline & & $\%$ & $68,8 \%$ & $21,0 \%$ & $8,3 \%$ & $1,2 \%$ & ,7\% & $100,0 \%$ & & & \\
\hline & \multirow{2}{*}{$\mathrm{E}$} & $\mathrm{n}$ & 284 & 120 & 29 & 4 & 6 & 443 & & & \\
\hline & & $\%$ & $64,1 \%$ & $27,1 \%$ & $6,5 \%$ & ,9\% & $1,4 \%$ & $100,0 \%$ & & & \\
\hline & \multirow{2}{*}{ Toplam } & $\mathrm{n}$ & 582 & 211 & 65 & 9 & 9 & 876 & & & \\
\hline & & $\%$ & $66,4 \%$ & $24,1 \%$ & $7,4 \%$ & $1,0 \%$ & $1,0 \%$ & $100,0 \%$ & & & \\
\hline \multirow{6}{*}{ 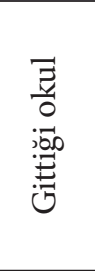 } & \multirow{2}{*}{$\begin{array}{c}\text { Devlet } \\
\text { okulu }\end{array}$} & $\mathrm{n}$ & 318 & 137 & 43 & 8 & 9 & 515 & \multirow{6}{*}{$18,550 \mathrm{a}$} & \multirow{6}{*}{4} & \multirow{6}{*}{, 001} \\
\hline & & $\%$ & $61,7 \%$ & $26,6 \%$ & $8,3 \%$ & $1,6 \%$ & $1,7 \%$ & $100,0 \%$ & & & \\
\hline & \multirow{2}{*}{$\begin{array}{l}\text { Özel } \\
\text { okul }\end{array}$} & $\mathrm{n}$ & 264 & 74 & 22 & 1 & 0 & 361 & & & \\
\hline & & $\%$ & $73,1 \%$ & $20,5 \%$ & $6,1 \%$ &, $3 \%$ & $0,0 \%$ & $100,0 \%$ & & & \\
\hline & \multirow{2}{*}{ Toplam } & $\mathrm{n}$ & 582 & 211 & 65 & 9 & 9 & 876 & & & \\
\hline & & $\%$ & $66,4 \%$ & $24,1 \%$ & $7,4 \%$ & $1,0 \%$ & $1,0 \%$ & $100,0 \%$ & & & \\
\hline \multirow{6}{*}{ 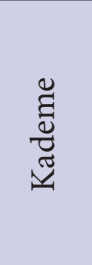 } & \multirow{2}{*}{ İlkokul } & $\mathrm{n}$ & 368 & 108 & 31 & 4 & 3 & 514 & \multirow{6}{*}{$16,231 \mathrm{a}$} & \multirow{6}{*}{4} & \multirow{6}{*}{,003 } \\
\hline & & $\%$ & $71,6 \%$ & $21,0 \%$ & $6,0 \%$ & $8 \%$ &, $6 \%$ & $100,0 \%$ & & & \\
\hline & \multirow{2}{*}{ Ortaokul } & $\mathrm{n}$ & 214 & 103 & 34 & 5 & 6 & 362 & & & \\
\hline & & $\%$ & $59,1 \%$ & $28,5 \%$ & $9,4 \%$ & $1,4 \%$ & $1,7 \%$ & $100,0 \%$ & & & \\
\hline & \multirow{2}{*}{ Toplam } & $\mathrm{n}$ & 582 & 211 & 65 & 9 & 9 & 876 & & & \\
\hline & & $\%$ & $66,4 \%$ & $24,1 \%$ & $7,4 \%$ & $1,0 \%$ & $1,0 \%$ & $100,0 \%$ & & & \\
\hline
\end{tabular}

Tablo 14b, "Çocuğun uzaktan eğitime katılma düzeyi nasıldı?” sorusuna verilen cevapların çocuğun cinsiyetine, gittiği okul türüne ve öğretim kademesine göre farklılaşma durumunu ortaya koymaktadır. Elde edilen bulgular şöyledir:

* "Çocuğun uzaktan eğitime katılma düzeyi nasıl oldu?" sorusuna verilen cevaplar ile çocuğun cinsiyeti arasında anlamlı bir bağıntı yoktur.

* “Çocuğun uzaktan eğitime alışma düzeyi nasıldı?" sorusuna verilen cevaplar ile çocuğun devam ettiği okulun türü arasında .01 düzeyinde anlamlı bir bağıntı vardır. Yüzdelik değerlere bakıldığında, ebeveynlerin görüşlerine göre, devlet okuluna devam eden çocukların \%88,3'ü uzaktan eğitime ya hiç aksatmadan ya da çoğunlukla katılmış görünmektedir. Buna karşın \%11,7’si ise bir düzen sağlayamamış görünmektedir. Özel okula giden çocukların ise \%93,6’sının ya hiç aksatmadan ya da çoğu zaman katılım sağladığı anlaşılmaktadır. Düzenli katılım sağlayamayan çocukların oranı ise \%6,4 olarak belirlenmiştir. Genel olarak değerlendirildiğinde devlet okuluna giden çocukların katılımlarında biraz daha sorun yaşanmış görünmektedir.

* “Çocuğun uzaktan eğitime alışma düzeyi nasıldı?” sorusuna verilen cevaplar ile çocuğun devam ettiği öğretim kademesi arasında .01 düzeyinde anlamlı bir bağıntı vardır. Yüzdelik değerlere bakıldığında, ebeveynlerin görüşlerine göre, ilkokula devam eden çocukların \%92,6'sı uzaktan eğitime ya hiç aksatmadan ya da çoğunlukla katılmıştır. Çocukların \%7,3’ü ise bir düzen sağlayamamıştır. Ortaokula giden çocukların ise \%87,6’sının ya hiç aksatmadan ya da çoğu zaman katılım sağladığı anlaşılmaktadır. Düzenli katılım sağlayamayan çocukların oranı ise \%12,4 olarak belirlenmiştir. Genel olarak değerlendirildiğinde uzaktan eğitime katılım açısından ortaokula devam eden çocukların daha fazla sorun yaşadıkları anlaşılmaktadır.

Tablo 15a ve 15b, "Çocuğun uzaktan eğitimle öğrenme kalitesi nasıldı?" sorusuna verilen cevaplar ile ilgili bulguları göstermektedir.

Tablo 15a: Çocuğun uzaktan eğitimle öğrenme kalitesi nasıldı?

\begin{tabular}{l|c|c}
\hline & $\mathrm{f}$ & $\%$ \\
\hline Çok iyiydi, hiç bir öğrenme sorunu yaşamadı & 123 & 14,0 \\
\hline Oldukça iyiydi, belirgin bir öğrenme sorunu yaşamadı & 285 & 32,5
\end{tabular}


Biraz iyiydi, arada sırada öğrenme sorunu yaşadı

İyi değildi, sık sık öğrenme sorunu yaşadı

Hiç iyi değildi, sürekli öğrenme sorunu yaşadı Toplam

\begin{tabular}{c|c}
318 & 36,3 \\
115 & 13,1 \\
35 & 4,0 \\
876 & 100,0 \\
\hline
\end{tabular}

Tablo 15a, salgın sürecinde çocukların uzaktan eğitimle öğrenme kalitesi hakkındaki sonuçları göstermektedir. Ebeveynlerin cevaplarına göre, çocukların toplam \%46,5’i ya hiçbir öğrenme sorunu yaşamadı ya da oldukça iyi öğrenmeler gerçekleştirdi. Buna karşın "biraz iyi olup arada sırada öğrenme sorunu yaşayan” çocukların toplam oranı \%50,3’tür. Hiç iyi olmayan ve öğrenme sorunu yaşayanların oranı ise \%4,0 olarak belirlenmiştir. Genel olarak bakıldığında, çocukların \%46,5’i öğrenme kalitesi açsından ya çok iyiydi ya da oldukça iyiydi. Buna karşın \%53,5’i az ya da çok öğrenme sorunu yaşadı. Bu oran oldukça yüksek görünmektedir.

Tablo 15b: "Çocuğun uzaktan eğitimle öğrenme kalitesi nasıldı?” sorusuna verilen cevapların çocuğun cinsiyeti, gittiği okul türü ve öğretim kademesi ile ilişkisi

\begin{tabular}{|c|c|c|c|c|c|c|c|c|c|c|c|}
\hline & & & 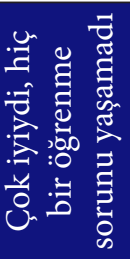 & 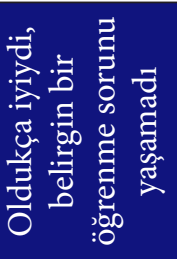 & 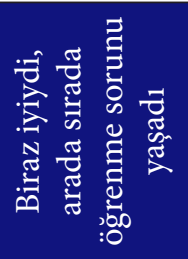 & 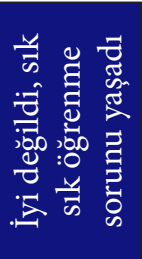 & 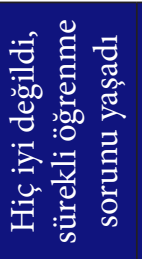 & 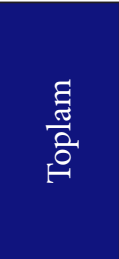 & $\chi$ & sd & $\mathrm{p}$ \\
\hline \multirow{6}{*}{ 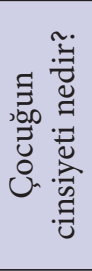 } & \multirow{2}{*}{$\mathrm{K}$} & $\mathrm{n}$ & 65 & 143 & 156 & 54 & 15 & 433 & \multirow{6}{*}{$1,542 \mathrm{a}$} & \multirow{6}{*}{4} & \multirow{6}{*}{,819 } \\
\hline & & $\%$ & $15,0 \%$ & $33,0 \%$ & $36,0 \%$ & $12,5 \%$ & $3,5 \%$ & $100,0 \%$ & & & \\
\hline & \multirow{2}{*}{$\mathrm{E}$} & $\mathrm{n}$ & 58 & 142 & 162 & 61 & 20 & 443 & & & \\
\hline & & $\%$ & $13,1 \%$ & $32,1 \%$ & $36,6 \%$ & $13,8 \%$ & $4,5 \%$ & $100,0 \%$ & & & \\
\hline & \multirow{2}{*}{ Toplam } & $\mathrm{n}$ & 123 & 285 & 318 & 115 & 35 & 876 & & & \\
\hline & & $\%$ & $14,0 \%$ & $32,5 \%$ & $36,3 \%$ & $13,1 \%$ & $4,0 \%$ & $100,0 \%$ & & & \\
\hline \multirow{6}{*}{ 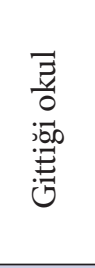 } & \multirow{2}{*}{$\begin{array}{l}\text { Devlet } \\
\text { okulu }\end{array}$} & $\mathrm{n}$ & 82 & 149 & 188 & 70 & 26 & 515 & \multirow{6}{*}{$11,823 a$} & \multirow{6}{*}{4} & \multirow{6}{*}{,019 } \\
\hline & & $\%$ & $15,9 \%$ & $28,9 \%$ & $36,5 \%$ & $13,6 \%$ & $5,0 \%$ & $100,0 \%$ & & & \\
\hline & \multirow{2}{*}{$\begin{array}{l}\text { Özel } \\
\text { okul }\end{array}$} & $\mathrm{n}$ & 41 & 136 & 130 & 45 & 9 & 361 & & & \\
\hline & & $\%$ & $11,4 \%$ & $37,7 \%$ & $36,0 \%$ & $12,5 \%$ & $2,5 \%$ & $100,0 \%$ & & & \\
\hline & \multirow{2}{*}{ Toplam } & $\mathrm{n}$ & 123 & 285 & 318 & 115 & 35 & 876 & & & \\
\hline & & $\%$ & $14,0 \%$ & $32,5 \%$ & $36,3 \%$ & $13,1 \%$ & $4,0 \%$ & $100,0 \%$ & & & \\
\hline \multirow{6}{*}{$\begin{array}{l}\stackrel{\Xi}{0} \\
\stackrel{\mathbb{U}}{\tilde{U}}\end{array}$} & \multirow{2}{*}{ İlkokul } & $\mathrm{n}$ & 92 & 188 & 180 & 42 & 12 & 514 & \multirow{6}{*}{$51,856 a$} & \multirow{6}{*}{4} & \multirow{6}{*}{,000 } \\
\hline & & $\%$ & $17,9 \%$ & $36,6 \%$ & $35,0 \%$ & $8,2 \%$ & $2,3 \%$ & $100,0 \%$ & & & \\
\hline & \multirow{2}{*}{ Ortaokul } & $\mathrm{n}$ & 31 & 97 & 138 & 73 & 23 & 362 & & & \\
\hline & & $\%$ & $8,6 \%$ & $26,8 \%$ & $38,1 \%$ & $20,2 \%$ & $6,4 \%$ & $100,0 \%$ & & & \\
\hline & \multirow{2}{*}{ Toplam } & $\mathrm{n}$ & 123 & 285 & 318 & 115 & 35 & 876 & & & \\
\hline & & $\%$ & $14,0 \%$ & $32,5 \%$ & $36,3 \%$ & $13,1 \%$ & $4,0 \%$ & $100,0 \%$ & & & \\
\hline
\end{tabular}

Tablo 15b, “Çocuğun uzaktan eğitimle öğrenme kalitesi nasıldı?” sorusuna verilen cevapların çocuğun cinsiyetine, gittiği okul türüne ve öğretim kademesine göre farklılaşma durumunu ortaya koymaktadır. Elde edilen bulgular şöyledir:

* “Çocuğun uzaktan eğitimle öğrenme kalitesi nasıldı?” sorusuna verilen cevaplar ile çocuğun cinsiyeti arasında anlamlı bir bağıntı yoktur.

* “Çocuğun uzaktan eğitimle öğrenme kalitesi nasıldı?” sorusuna verilen cevaplar ile çocuğun devam ettiği okulun türü arasında .05 düzeyinde anlamlı bir bağıntı vardır. Yüzdelik değerlere bakıldığında, ebeveynlerin görüşlerine göre, devlet okuluna devam eden çocukların \%44,8'inin öğrenme kalitesi ya çok iyiydi ya da oldukça iyiydi. Buna karşın \%55,2'si ise öğrenme açısından az ya da çok sorun yaşamıştır. Özel okula gidenler açısından ise durum şöyledir: Çocukların \%49,1'i öğrenme açısından bir sorun yaşamamış görünmektedir. \%50,9'u ise az ya da çok sorun yaşamış görünmektedir. Her iki okul türüne devam eden çocukların öğrenme kalitesine bakıldığında, hiç sorun yaşamayan uçta olanlar ile sürekli sorun yaşayan uçta olan çocukların daha çok devlet okuluna devam eden çocuklar olduğu anlaşılmaktadır.

* “Çocuğun uzaktan eğitimle öğrenme kalitesi nasıldı?” sorusuna verilen cevaplar ile çocuğun devam ettiği 
öğretim kademesi arasında .01 düzeyinde anlamlı bir bağıntı vardır. Yüzdelik değerlere bakıldığında, ebeveynlerin görüşlerine göre, ilkokula devam eden çocukların \%54,5'inin genel olarak öğrenme sorunu yaşamadığı görülmektedir. Buna karşın, $\% 45,5$ ’i ise az ya da çok öğrenme sorunu yaşamıştır. Ortaokula devam eden çocukların ise \%35,4'ünün öğrenme kalitesinde bir sorun olmamıştır. Öğrenme kalitesinde az ya da çok sorun yaşayanların oranı ise \%64,6 olarak belirlenmiştir. Uzaktan eğitimin öğrenme kalitesine en olumsuz etkisi ortaokul çocuklarına yönelik olmuş görünmektedir.

Tablo 16a ve 16b, “Çocuğun uzaktan eğitimle verilen ödevleri yapma alışkanlığı nasıldı?” sorusuna verilen cevaplar ile ilgili bulguları göstermektedir.

Tablo 16a: Çocuğun uzaktan eğitimle verilen ödevleri yapma alışkanlığı nasıldı?

\begin{tabular}{l|c|c|}
\hline & f & $\%$ \\
\hline Çok iyiydi, düzenli olarak yaptı & 282 & 32,2 \\
İyiydi, genellikle düzenli olarak yaptı & 391 & 44,6 \\
Kısmen iyiydi, nadiren yaptı & 135 & 15,4 \\
İyi değildi, nadiren yaptı & 42 & 4,8 \\
Hiç iyi değildi, neredeyse hiç yapmadı & 26 & 3,0 \\
\hline Toplam & 876 & 100,0 \\
\hline
\end{tabular}

Tablo 16a, salgın sürecinde çocukların uzaktan eğitimle verilen ödevleri yapma alışkanlığı ile ilgili sonuçları göstermektedir. Ebeveynlerin cevaplarına göre, çocukların toplam \%56,8’i ödevlerini yapma konusunda çok iyiydi ve düzenli olarak yaptı ya da iyiydi ve genellikle düzenli olarak yaptı. Ödevlerini kısmen iyi olup nadiren yapan ve iyi olmayın nadiren yapan çocukların oranı ise toplam \%20,2 olmuştur. Ödevlerini neredeyse hiç yapmayan çocukların oranı ise \%3,0'dir. Sonuçlar genel olarak ele alındığında, çocukların \%56,8'inin ödev yapma alışkanlığında bir sorun olmamış görünmektedir. \%43,2'sinin ise az ya da çok sorun yaşadığı anlaşılmaktadır. Bu da dikkati çekici bir orandır.

Tablo 16b: "Çocuğun uzaktan eğitimle verilen ödevleri yapma alışkanlığı nasıldı?” sorusuna verilen cevapların çocuğun cinsiyeti, gittiği okul türü ve öğretim kademesi ile ilişkisi

\begin{tabular}{|c|c|c|c|c|c|c|c|c|c|c|c|}
\hline & & & 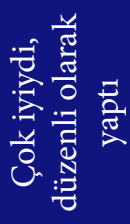 & 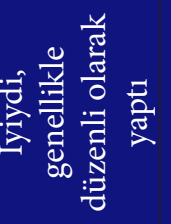 & 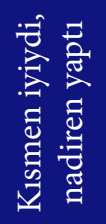 & 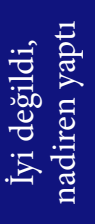 & 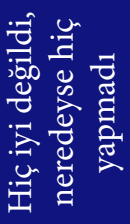 & $\frac{\text { E }}{\frac{\text { ज्ञ }}{0}}$ & $\chi$ & sd & $\mathrm{p}$ \\
\hline \multirow{6}{*}{ 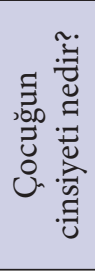 } & \multirow{2}{*}{$\mathrm{K}$} & $\mathrm{n}$ & 148 & 194 & 68 & 14 & 9 & 433 & \multirow{6}{*}{$7,741 \mathrm{a}$} & \multirow{6}{*}{4} & \multirow{6}{*}{,102 } \\
\hline & & $\%$ & $34,2 \%$ & $44,8 \%$ & $15,7 \%$ & $3,2 \%$ & $2,1 \%$ & $100,0 \%$ & & & \\
\hline & \multirow{2}{*}{$\mathrm{E}$} & $\mathrm{n}$ & 134 & 197 & 67 & 28 & 17 & 443 & & & \\
\hline & & $\%$ & $30,2 \%$ & $44,5 \%$ & $15,1 \%$ & $6,3 \%$ & $3,8 \%$ & $100,0 \%$ & & & \\
\hline & \multirow{2}{*}{ Toplam } & $\mathrm{n}$ & 282 & 391 & 135 & 42 & 26 & 876 & & & \\
\hline & & $\%$ & $32,2 \%$ & $44,6 \%$ & $15,4 \%$ & $4,8 \%$ & $3,0 \%$ & $100,0 \%$ & & & \\
\hline \multirow{6}{*}{ 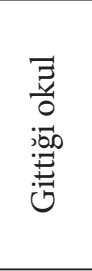 } & \multirow{2}{*}{$\begin{array}{l}\text { Devlet } \\
\text { okulu }\end{array}$} & $\mathrm{n}$ & 148 & 210 & 99 & 34 & 24 & 515 & \multirow{6}{*}{$41,155 \mathrm{a}$} & \multirow{6}{*}{4} & \multirow{6}{*}{, 000} \\
\hline & & $\%$ & $28,7 \%$ & $40,8 \%$ & $19,2 \%$ & $6,6 \%$ & $4,7 \%$ & $100,0 \%$ & & & \\
\hline & \multirow{2}{*}{$\begin{array}{l}\text { Özel } \\
\text { okul }\end{array}$} & $\mathrm{n}$ & 134 & 181 & 36 & 8 & 2 & 361 & & & \\
\hline & & $\%$ & $37,1 \%$ & $50,1 \%$ & $10,0 \%$ & $2,2 \%$ &, $6 \%$ & $100,0 \%$ & & & \\
\hline & \multirow{2}{*}{ Toplam } & $\mathrm{n}$ & 282 & 391 & 135 & 42 & 26 & 876 & & & \\
\hline & & $\%$ & $32,2 \%$ & $44,6 \%$ & $15,4 \%$ & $4,8 \%$ & $3,0 \%$ & $100,0 \%$ & & & \\
\hline \multirow{6}{*}{ 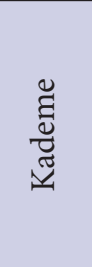 } & \multirow{2}{*}{ İlkokul } & $\mathrm{n}$ & 173 & 246 & 68 & 17 & 10 & 514 & \multirow{6}{*}{$17,688 \mathrm{a}$} & \multirow{6}{*}{4} & \multirow{6}{*}{,001 } \\
\hline & & $\%$ & $33,7 \%$ & $47,9 \%$ & $13,2 \%$ & $3,3 \%$ & $1,9 \%$ & $100,0 \%$ & & & \\
\hline & \multirow{2}{*}{ Ortaokul } & $\mathrm{n}$ & 109 & 145 & 67 & 25 & 16 & 362 & & & \\
\hline & & $\%$ & $30,1 \%$ & $40,1 \%$ & $18,5 \%$ & $6,9 \%$ & $4,4 \%$ & $100,0 \%$ & & & \\
\hline & \multirow{2}{*}{ Toplam } & $\mathrm{n}$ & 282 & 391 & 135 & 42 & 26 & 876 & & & \\
\hline & & $\%$ & $32,2 \%$ & $44,6 \%$ & $15,4 \%$ & $4,8 \%$ & $3,0 \%$ & $100,0 \%$ & & & \\
\hline
\end{tabular}

Tablo 16b, “Çocuğun uzaktan eğitimle verilen ödevleri yapma alı̧kanlığı nasıldı?” sorusuna verilen cevapların çocuğun cinsiyetine, gittiği okul türüne ve öğretim kademesine göre farklılaşma durumunu ortaya koymaktadır. Elde 
edilen bulgular şöyledir:

* “Çocuğun uzaktan eğitimle verilen ödevleri yapma alışkanlığı nasıldı?” sorusuna verilen cevaplar ile çocuğun cinsiyeti arasında anlamlı bir bağıntı yoktur.

* “Çocuğun uzaktan eğitimle verilen ödevleri yapma alışkanlığı nasıldı?” sorusuna verilen cevaplar ile çocuğun devam ettiği okulun türü arasında .01 düzeyinde anlamlı bir bağıntı vardır. Yüzdelik değerlere bakıldığında, ebeveynlerin görüşlerine göre, devlet okuluna devam eden çocukların \%69,5'inin ödev yapma alışkanlığ iyi görünmektedir. Ancak, çocukların \%30,5’inin ödev yapma alışkanlığında az ya da çok sorunlar olduğu söylenebilir. Özel okula devam eden çocukların ise \%87,2'sinin ödev yapma alışkanlığında sorun olmadığ görülmektedir. Buna karşın \%12,8’inin az ya da çok sorun yaşadığı söylenebilir. Genel olarak bakıldığında, devlet okuluna devam eden çocukların belirgin düzeyde ödev alışkanlıkları özel okula devam eden çocuklardan daha olumsuzdur.

* “Çocuğun uzaktan eğitimle verilen ödevleri yapma alışkanlığı nasıldı?” sorusuna verilen cevaplar ile çocuğun devam ettiği öğretim kademesi arasında .01 düzeyinde anlamlı bir bağıntı vardır. Yüzdelik değerlere bakıldığında, ebeveynlerin görüşlerine göre, ilkokula devam eden çocukların \%81,6'sının genel olarak ödev yapma alışkanlıklarının yeterli olduğu söylenebilir. Buna karşın, \%8,4'ü ise az ya da çok ödev yapma sorunu yaşamış görünmektedir. Ortaokula devam eden çocukların ise \%70,2'sinin ödev yapma alışkanlıkları yeterlidir. Bununla birlikte, \%29,8'i ise az ya da çok sorunlar yaşamaktadır. İlkokul ve ortaokula devam eden çocuklar genel olarak karşılaştırıldığında, ortaokul çocuklarının daha fazla sorun yaşadığı söylenebilir.

\section{SONUÇ VE TARTIŞMA}

Araştırma, covid 19 salgın sürecinin çocukların günlük yaşam alışkanlıkları, duygudurumları ve uzaktan eğitime yönelik davranışları üzerindeki etkilerini ortaya koymayı amaçlamıştır. Bu kapsamda dört temel alt boyutta konu ele alınmıştır:

1. Salgın sürecinin çocukların günlük yaşam alışkanlıklarına etkileri

2. Salgın sürecinin çocukların duygudurumlarına etkileri

3. Salgın sürecinin çocukların sosyal ilişkilerine etkileri

4. Salgın sürecinin çocukların uzaktan eğitimi sürecine etkileri

Salgın sürecinin çocuklar üzerindeki etkileri ayrıca çocukların cinsiyetleri, devam ettikleri okul türü ve öğretim kademelerine göre de karşılaştırılmıştır.

\section{Salgın sürecinin çocukların günlük yaşam alışkanlıklarına etkileri ile ilgili sonuçlar}

* Çocukların uyku düzeni genel olarak salgın öncesine göre daha çok olumsuz yönde değişikliğe uğramıştır. Devlet okuluna giden çocukların uyku düzenlerinde özel okula giden çocuklara göre daha olumsuz yönde değişiklik olmuştur.

* Çocukların yemek düzenleri salgın öncesi zamana göre daha olumsuz yönde değişmiştir. Ortaokula devam eden çocukların yemek düzenleri, ilkokula devam eden çocuklara göre daha olumsuz yönde değişmiştir.

* Çocukların kıyafet giyip çıkarma davranışları salgın öncesi zamana göre dikkati çekici düzeyde olumsuz yönde değişmiştir. Olumsuz yönde değişiklik daha çok özel okula giden çocuklarda olurken olumlu yönde değişiklik ise daha çok devlet okuluna giden çocuklarda olmuştur. Öğretim kademeleri açısından, olumsuz değişikliğin daha çok ortaokula devam eden çocuklarda, olumlu değişikliğin ise ilkokula devam eden çocuklarda olduğu anlaşılmaktadır.

* Çocukların temizlik alışkanlıkları salgın öncesine göre belirgin düzeyde olumlu yönde değişmiştir. Devlet okuluna giden çocukların temizlik alışkanlıkları özel okula giden çocuklara göre daha fazla olumlu yönde değişmiştir. Öğretim kademeleri açısından yapılan karşılaştırmaya göre, ilkokula devam eden çocukların temizlik alışkanlıklarında ortaokula devam eden çocuklara göre daha belirgin düzeyde olumlu değişiklikler olmuştur. Olumsuz değişiklikler ise daha çok ortaokula devam eden çocuklarda olmuştur. 
Salgın sürecinin etkileri ile ilgili İnsan Hakları Derneği 1-18 yaş çocuklarına yönelik 366 katılımcı ile bir araştırma yapmıştır. Uyku ile ilgili soruya cevap veren katılımcı sayısı 241'dir. 241 kişiden 132 (\%55)'sinin uykusu artmış, 58'inin azalmış, 51'inde ise bir değişiklik olmamıştır. Uykusu artanların çoğu da kız çocuklarıdır (İnsan Hakları Derneği, 2021). SGDD Göç Akademisi Türkiye genelinde 49 ilde 1133 sığınmacı ebeveynin katılımıyla bir araştırma gerçekleştirilmiştir. Bu araştırmada, her 100 çocuktan 55'inin yemek ve iştah, 49'unun ise uyku sorunları yaşadığı tespit edilmiştir (SGDD, 2021).

Elde edilen bulgular değerlendirildiğinde, covid 19 salgın sürecinin, çocukların temizlik alışkanlığı dışındaki günlük yaşam alışkanlıklarını daha çok olumsuz yönde etkilediği söylenebilir. Covid 19 virüsünün bulaşıcı olması nedeniyle temizlik davranışı kritik öneme sahiptir. Bütün dünyada bütün devletler ve sağlık örgütleri temizliğe yaptığı vurgu nedeniyle toplumsal hassasiyeti artırmışlar; bu da doğal olarak çocukların davranışlarına da yansımıştır. Ancak, bunun dışındaki yemek düzeni, uyku düzeni ve kıyafet giyip çıkarma davranışları az ya da çok bozulmuş görünmektedir. Çocuklar için günlük rutin önemlidir. Salgının bu rutini bozması nedeniyle çocukların yemek yeme, uyuma ve kıyafetlerini giyip çıkarma hassasiyetleri azalmış olabilir. Ebeveynlerin bu konularda yapmış olabilecekleri yönlendirmelerin etkisinin de yeterli olmadığı söylenebilir.

\section{Salgın sürecinin çocukların duygudurumlarına etkileri ile ilgili sonuçlar}

* Çocukların kaygı düzeyleri salgın öncesi zamana göre belirgin düzeyde artmıştır.

* Çocukların öfke düzeyleri salgın öncesi zamana göre belirgin düzeyde artmıştır.

* Çocukların korku düzeyleri salgın öncesi zamana göre belirgin düzeyde artmıştır. Devlet okuluna giden çocukların korku düzeyleri özel okula giden çocuklardan daha fazla artmıştır.

* Çocukların mutluluk (neşe) düzeyleri salgın öncesi zamana göre belirgin düzeyde azalmıştır. Devlet okuluna giden çocukların mutluluk düzeyleri özel okula giden çocuklara göre daha fazla azalmıştır. Ortaokula giden çocukların mutluluk düzeyleri de ilkokula giden çocukların mutluluk düzeylerine göre daha çok azalmış görünmektedir.

İnsan Hakları Derneği’nin araştırmasında çocukların kaygı düzeylerinde değişiklik olup olmadığına dair ebeveynlere sorulan soruya 214 katılımcı evet (\%59), değişiklik oldu; 147 katılımcı hayır (\%40), değişiklik olmadı şeklinde cevap vermiştir. 5 katılımcı bu soruyu cevaplamamıştır (İnsan Hakları Derneği, 2021). TOÇEV’in desteklediği ve 101 ilkokul ve ortaokul öğrencisi ile yapılan araştırmada elde edilen sonuçlara göre, salgın süreciyle birlikte ilkokul ve ortaokula devam eden çocukların \%55,1'inin gelecek kaygısı yaşadığı, \%46,9'unun ise salgın sonrası hayata karışma ile ilgili kaygı yaşayacağı belirtilmektedir (TOÇEV, 2021). SGDD Göç Akademisi’nin yaptığı araştırmada çocukların duygudurumları ile ilgili elde edilen sonuçlara göre her 100 çocuktan 40’1 salgın süresince kaygı, üzüntü, korku, öke, keyifsizlik duygularından en az birini sıklıkla yaşamıştır. Yine her 100 çocuktan 57'si öfke yaşamış; itme, vurma, 1sırma, inatlaşma ve kavga etme gibi davranışlar sergilemiştir (SGDD, 2021). ABD'de Nisan 2020'de 405 ebeveyne salgın ile ilgili anket uygulaması yapılmıştır. Araştırma sonuçlarına göre ebeveynlerin üçte birinden fazlası $(\% 34,7)$, çocuklarının davranışlarının salgından bu yana üzgün ve depresif olma yönünde değiştiğini söylemiştir (Shawna, Kaitlin, Olivia, Kasey, 2021).5823 katılımcı ile yapılan bir araştırmada, salgın süreci ile ilgili özellikle ergenlerin duygusal sorunlarında büyük artışlar olduğu ortaya konmuştur (Schmidt, Barblan, Lory and Landolt, 2021). Çin'de Şubat 2020 boyunca çevrimiçi anket kullanılarak yapılan araştırmada çocuklardan $(n=1360)$ ve ebeveynlerinden $(n=1360)$ veri toplanmıştır. Sonuçlar, çocuklarda \%1,84’ünün orta derecede anksiyete yaşadığını, \%2,22'sinin depresyon yaşadığını ve \%3,16’sının TSSB tanı kriterlerini karşıladığını ortaya koymaktadır (Yue, Zang, Le, An, 2020). İtalya ve İspanya’da çocuklarla ilgili yapılan bir araştırmada, evde kalma sürecinde çocukların \%31'i yalnızlık hissi, \%38'i sinirlilik, \%39'u huzursuzluk, \%77'si dikkatte odaklanamama sorunları yaşadığı tespit edilmiştir (UN, 2020). Almanya'da 26 Mayıs ve 10 Haziran tarihleri arasında 7-17 yaş arası çocukları ve ergenleri olan 1586 aile ile çevrimiçi anket gerçekleştirilmiştir. Bulgulara göre, çocukların ve ergenlerin üçte ikisinin, salgın nedeniyle yüksek oranda stres yükü altında olduğu tespit edilmiştir. Salgın öncesine kıyasla önemli ölçüde daha fazla zihinsel sağlık sorunu ve daha yüksek kaygı düzeyine sahip oldukları sonucuna ulaşılmıştır. Sosyoekonomik durumu düşük, göç geçmişi olan ve yaşam alanı kısıtlı olan çocuklar önemli ölçüde daha fazla etkilenmiştir (Ravens-Sieberer and others, 2021). Avrupada 7 ülkede araştırma yapılmıştır. Birleşik Krallık ( $n=508)$, İsveç $(n=1436)$, İspanya $(n=1491)$, Belçika $(n=508)$, Holanda $(n=324)$, Almanya $(n=1662)$ ve İtalya (n=794)'dan toplam 6720 ebeveynin katılımıyla yapılan araştırmada, evde eğitimin düşük kalitede olduğu, hem çocuklar hem de ebeveynler üzerinde olumsuz etkiler yaşandığı bulunmuştur. Aile içinde stres, endişe, sosyal 
izolasyon ve çatışma seviyelerinin arttığını belirlenmiştir. Az sayıda ebeveynde de, alkol ve uyuşturucu kullanımının arttığ 1 tespit edilmiştir (Thorell and oth., 2020). Hindistan'da salgın süresince karantinaya alınan 121 çocuk, ergen ve bunların ebeveynleri ile görüşmeler yapıldı. Sonuçlar, karantinaya alınmayan 131 çocuk ve ergenin sonuçlarıyla karşılaştırıldı. Elde edilen bulgulara göre, karantinaya alınan çocuk ve ergenler, alınmayanlara göre çok daha büyük psikolojik sıkıntılar yaşadılar. Karantina altındaki çocukların en sık yaşadıkları duygular endişe $(\% 68,59)$, çaresizlik $(\% 66,11)$ ve korku $(\% 61,98)$ oldu ( Saurabh and Ranjan, 2020).

Araştırmalardan elde edilen bulgular, salgın sürecinin çocukların kaygı düzeylerini genel olarak artırdığını göstermektedir. Bu sonuç beklenen bir durum olarak görülebilir. Öyle görünüyor ki, covid 19 salgın süreci aile ortamlarını etkilemiş; bu da kaçınılmaz olarak çocuklara yansımıştır. Bu kaygının önemli olacağı, kaygıya bağlı sorunların da salgın sonrasında artabileceği söylenebilir.

\section{Salgın sürecinin çocukların sosyal ilişkilerine etkileri ile ilgili sonuçlar}

* Çocukların çoğu annesiyle ilişkilerinde salgın öncesine göre daha olumsuz (tepkisel, içine kapanık, az iletişim kurma, değişken davranışlar sergileme vb.) ilişkiler kurmuştur. Özel okula giden çocuklar, devlet okuluna giden çocuklara göre daha olumsuz iletişim kurmuştur. Ayrıca, ortaokula devam eden çocuklar ilkokula devam eden çocuklara göre daha olumsuz iletişim kurmuştur.

* Çocukların dikkate değer bir bölümü, babalarıyla ilişkilerinde salgın öncesine göre daha olumsuz (tepkisel, içine kapanık, az iletişim kurma, değişken davranışlar sergileme vb.) ilişkiler kurmuştur. Olumsuz iletişim kuran çocukların çoğu özel okula devam eden çocuklardır. Yine, ortaokula devam eden çocuklar da ilkokula devam eden çocuklara göre daha olumsuz iletişim kurmuştur.

* Çocukların dikkate değer bir bölümü salgın öncesine göre kardeş(ler)iyle daha olumsuz ilişkiler (tepkisel, içine kapanık, az iletişim kurma, değişken davranışlar sergileme vb.) kurmuştur. Olumsuz ilişki kuranların çoğu kız çocuğudur. Ayrıca, devlet okuluna gidenler özel okula gidenlere göre daha fazla olumsuz ilişki kurmuşlardır.

* Çocukların yarıdan fazlası öğretmenlerini özlemiş görünmektedir. Özleyenlerin çoğu kız öğrencilerdir. Öğretim kademesi açısından bakıldığında, ilkokula devam eden öğrencilerin ortaokul öğrencilerine göre daha çok özlediği anlaşılmaktadır.

İnsan Hakları Derneği (2021)'nin 243 kişi üzerinde yaptığı araştırmada 62 katılımcı okulunu ve okula gitmeyi özlediğini belirtmiştir. Benzer şekilde, 2019-2020 öğretim yılında Muş ilinde 14 anne ile yapılan görüşmede, 12 veli çocuklarının öğretmenini çok özlediğini ifade etmiştir (Demir-Öztürk, Kuru, Demir-Yıldız, 2020). SGDD Göç Akademisi'nin 2021'de yayınladığı araştırmanın diğer sonuçları, her 100 çocuktan 30'unun ailesi ve akranlarıyla iletişim kurmakta zorlandığını göstermiştir. Ayrıca bu çocukların 90’ının bu süreçte sorunlarla ilgili herhangi bir doktor, psikolog, öğretmen vb. uzman desteği almadığı belirlenmiştir (SGDD, 2021).

Salgın süreciyle birlikte yaşanan eve kapanmalar, aile içi ilişkileri etkilemiş görünmektedir. Dikkate değer düzeyde çocuklar anne-babalarıyla, arkadaşlarıyla ilişki ve iletişim sorunları yaşamıştır. Salgından sonraki süreçte ilişkilerde yaşanan bu sorunların çözümünün zaman alacağı söylenebilir.

\section{Salgın sürecinin çocukların uzaktan eğitimle ilgili davranışları üzerindeki etkileri ile ilgili sonuçlar}

* Çocukların neredeyse dörtte üçünün az ya da çok uzaktan eğitime yeterince alışamadığı anlaşılmaktadır. Alt gruplar karşılaştırıldığında, erkek çocukların kız çocuklarına göre, devlet okuluna giden çocukların özel okula giden çocuklara göre, ortaokula devam eden çocukların da ilkokula devam eden çocuklara göre daha fazla alışma sorunu yaşadıkları görülmektedir.

* Çocukların oldukça büyük bölümü, uzaktan eğitime aksatmadan katılmıştır. Her on çocuktan birinin uzaktan eğitime katılma ile ilgili az ya da çok sorun yaşadığı anlaşılmaktadır. Sorun yaşayan çocuklarla ilgili alt gruplar karşılaştırıldığında, devlet okuluna gidenler özel okula gidenlere göre, ortaokula gidenler ilkokula gidenlere göre daha fazla sorun yaşamış görünmektedir.

* Çocukların yarıdan biraz fazlasının öğrenme kalitesinin iyi olmadığı gözlemlenmiştir. Alt grup karşılaştırılmalarına bakıldığında, seçeneklerden en uç değer olan ve sorunu sürekli yaşayanlar daha çok devlet okuluna gidenler olmuştur. Yine, ortaokula devam eden çocuklar ilkokul çocuklarına göre daha fazla öğrenme 
sorunu yaşamış görünmektedir.

* Çocukların yarıya yakını uzaktan eğitim sürecinde ödev yapma ile ilgili sorunlar yaşamıştır. Alt grup karşılaştırmalarına göre, ödev yapma sorununu devlet okuluna giden çocuklar daha yoğun yaşamıştır. Ayrıca, ortaokula devam eden çocukların ilkokula devam eden çocuklara göre ödev sorunlarını daha çok yaşadığı anlaşılmaktadır.

İnsan Hakları Derneği’nin 243 kişi üzerinde yaptığı araştırmada katılımcıların 16’sı online eğitimi çok yararlı, 71’i yararl, 108'i az yararlı, 37'si yararsız bulurken 11'i zararlı bulmuşlardır (İnsan Hakları Derneği, 2021). TOÇEV'in desteklediği ve 101 ilkokul ve ortaokul öğrencisi ile yapılan araştırmada, öğrencilerin \%47,5’i online derslere odaklanmakta zorlandığ 1 sonucuna ulaşılmıştır. Öğrencilerin \%57,1’i ise uzaktan eğitim/iş sürecinin ne zaman biteceğini bilmemelerinin eğitim hayatlarını olumsuz etkilediğini belirtmektedir (TOÇEV, 2021). Orhan ve diğerleri (2021)'nin yaptığı araştırmanın bulgularına göre öğrencilerin \%61,1'i okulda yapılan yüz yüze derslerde, ekrandan yapılan çevrimiçi derslere göre daha iyi öğrendiklerini belirtmişlerdir. Çevrimiçi derslere düzenli olarak devam eden öğrencilerin öğrenme algıları ile düzenli girmeyenlerin öğrenme algıları arasında anlamlı farklar görülmüştür. Covid-19 döneminde dersleri çevrimiçi olarak düzenli takip eden öğrencilerin \%47.8'i çevrimiçi ortamda öğrendiğini belirtirken, bu oran derslere bazen girip bazen girmeyen öğrencilerde \%2,2’ye düşmektedir. Öğrencilerin öğrenme algıları üzerinde zevk ve sıkılma duygularının oldukça yüksek, kaygı duygusunun orta düzeyde etkili olduğu, yalnızlık duygusunun etkisinin ise çok sınırlı olduğu görülmüştür. 2019-2020 öğretim yılında Muş ilinde 14 anne ile yapılan görüşmeden elde edilen diğer bir sonuç da, çocuklarının uzaktan eğitimi sevmediği yönündedir (Demir-Öztürk, Kuru, Demir-Ylldız, 2020).

Farklı araştırmalarda elde edilen bulgular genel olarak değerlendirildiğinde çocukların uzaktan eğitimle ilgili duygu ve düşüncelerinin dikkate değer düzeyde olumsuz olduğu söylenebilir. Buna karşın yaşanan tecrübeler uzaktan eğitimin artık eğitimin bir parçası haline geleceğini göstermektedir. Bugünkü haliyle uzaktan eğitimin çocuklar için yeterince çekici olmadığı gerçeğinden hareketle uygulamanın daha da geliştirilmesi gerektiği açıktır.

Covid 19 salgın sürecinin olumsuz etkilerini ortadan kaldırmak için aşağıdaki öneriler yol gösterici olabilir:

* Çocukların salgın sonrasına uyum sağlaması için okullarda ailelere yönelik destekleyici eğitimlerin düzenlenmesi düşünülmelidir.

* Okullarda rehberlik birimleri tarafından müdahale programları geliştirilerek çocukların okula uyum sağlama, kaygı ile başa çıkma, öfke kontrolü, çatışma çözme gibi sorunlarının çözümüne katkı sağlanmalıdır.

* Sivil toplum kuruluşları tarafından salgın sürecinin olumsuz etkilerinin giderilmesine yönelik destekleyici programlar geliştirilmeli ve çeşitli kurumlarla iş birliği yaparak uygulanması sağlanmalıdır.

* Uzaktan eğitim sürecinin, örgün eğitimin bir parçası olacağı ve hibrit eğitimin süreklilik kazanacağı gerçeğini dikkate alarak sürece yayılmış şekilde online eğitim platformlarının geliştirilmesine devam edilmelidir. Bu teknolojilerin geliştirilmesinde etkili öğretim modelleri ve yöntemlerinden yararlanılmalıdır.

* Okullarda olası akran sorunlarının çözümüne yönelik önleyici ve geliştirici etkinlikler düzenlenmeli, sosyal faaliyetler organize edilmeli, oyunlaştırılmış ortamlarda paylaşımlara fırsat verilmelidir.

* Salgın sürecinden olumlu etkilenen gruplar ile olumsuz etkilenen grupların özelliklerinin karşılaştırılmasına yönelik ayrıntılı araştırmalar yapılmalıdır.

\section{KAYNAKLAR}

Akkan, B. (2020). “Kovid-19’un Çocuklar Üzerinde Etkisi ve Çocuk Odaklı Sosyal Politikalar”, TESEV Değerlendirme Notları: 2020/6.

Aslan, R. (2020). Tarihten Günümüze Epidemiler, Pandemiler ve Covid-19. Ayrıntı Dergisi, 8(65, 35-41.

Çelik, Ş. ve Çak, E. (2021). "Covid 19 Sürecinin Aile Üzerindeki Etkisi”, Arrival Date: 18.02.2021, Published Date: 25.03.2021, 2021, Vol: 6, Issue: 11, pp: 43-49, Doi Number: http://dx.doi.org/10.46648/gnj.185

Demir Öztürk, E., Kuru, G., Demir-Yıldız, C. (2021). Covid 19 pandemi günlerinde anneler ne düşünür çocuklar ne ister? Anne ve çocuklarının pandemi algısı, Avrasya Sosyal ve Ekonomi Araștırmaları Dergisi (ASEAD) Eurasian Journal of Researches in Social and Economics (EJRSE) ISSN:2148-9963, Asead Cilt 7, Say1 5, Y1l 2020, ss.204-220 
Garfield, R., Chidambaram, P. (2020). “Children's Health and Well Being During the Coronavirus Pandemic”, Published: Sep 24, 2020, https://www.kff.org/coronavirus-covid-19/issue-brief, Erişim Tarihi: 25.10.2021.

İnsan Hakları Derneği (2021). Pandemi Döneminde Çocukların Durumu Araştırması (Ed. Meltem Akboğa), https://www.ihd. org.tr/wp-content/uploads/2021/01/20210104_PandemideCocuklar.pdf, Erişim Tarihi: 22.10.2021

Lee J. (2020). Mental health effects of school closures during, Covid 19 Lancet Child Adoles Health, April 14, 2020, doi: https://doi. org/10.1016/S2352-4642(20)30109-7

MEB Strateji Geliştirme Başkanlığ1 (2021). Milli Eğitim İstatistikleri, Örgün Eğitim 2020/’21, Ankara: Resmi İstatistik Programı Yayinı.

Orhan, F., Yılmaz, M. B., Bayrak, İ. ve Zeren, Ş. G. (2021). “COVID-19 Sürecinde Uzaktan Öğretme Süreci İle İlgili İlk ve Ortaöğretim Öğrencilerinin Algıları ve Duygularına Yönelik Bir Analiz”, Covid 19 ve Toplum: Salgının Sosyal, Beşeri ve Ekonomik Etkileri. Bulgular, Sonuçlar ve Öneriler. T.C. Sanayi ve Teknoloji Bakanlığı ve Tübitak, https://tubitak.gov.tr/sites/ default/files/20689, Erişim Tarihi: 25.10.2021

Politika Notu (2020). Politika Notu: Covid-19 Salgınının Çocuklar Üzerindeki Etkisi, 15 Nisan 2020.

Ravens-Sieberer, U., Kaman, A., Erhart, M., Devine, J., Schlack, R. and Otto, C. (2021). Impact of the COVID-19 pandemic on quality of life and mental health in children and adolescents in Germany, European Child \& Adolescent Psychiatry.

Sarı, T., Nayır, F. (2020). Pandemi dönemi eğitim: sorunlar ve fursatlar. Turkish Studies, 15(4), 959-975. https://dx.doi.org/10.7827/ TurkishStudies.44335

Schmidt, S. J., Barblan, L. P., Lory, I. and Landolt, M. A. (2021). Age-related effects of the COVID-19 pandemic on mental health of children and adolescents, European Journal of Psychotraumatology. 12:1, 1901407, DOI: 10.1080/20008.198.2021.1901407, https://doi.org/10.1080/20008.198.2021.1901407; Erişim Tarihi: 27.10.2021.

Schonfeld, D. J. and Demaria, T. (2015). Providing psychosocial support to children and families in the aftermath of disasters and crises. Pediatrics, 136 (4), 1120-1130.

SGDD Göç Akademisi (2021). Covid 19 Pandemisinin Türkiye’deki Uluslararası ve Geçici Koruma Altındaki Çocuklar Üzerinde Etkileri (Nisan 2021). https://sgdd.org.tr, Erişim Tarihi: 25.10.2021

Saurabh, K. and Ranjan, S. (July 2020). Compliance and psychological impact of quarantine in children and adolescents due to covid-19 pandemic, The Indian Journal of Pediatrics. 87(7): 532-536, https://doi.org/10.1007/s12098.020.03347-3 The India, Erişim Tarihi: 18.11.2021.

Shawna J. L., Kaitlin, P. W., Olivia, D. C., Kasey, M. D. (2021). "Parenting activities and the transition to home-based education during the COVID-19 pandemic", Children and Youth Services Review. Volume: 122, March 2021, 105585, https://doi. org/10.1016/j.childyouth.2020.105585

The World Bank (2021). "Simulating the Potential Impacts of COVID-19 School Closures on Schooling and Learning Outcomes: A Set of Global Estimates (English)", https://documents.worldbank.org/en/publication/documents-reports/ documentdetail/329.961.592483383689, Erişim Tarihi: 25.10.2021.

TOÇEV. TOÇEV Covid-19 Etki Raporu, tocev.org.tr, Erişim Tarihi: 25.10.2021.

Thorell, L. B., Skoglund, C. B., de la Peña, A. G., Baeyens, D., Fuermaier, A., Groom, M., Christiansen, H. (2020, September 25). Psychosocial effects of homeschooling during the COVID-19 pandemic: Differences between seven European countries and between children with and without mental health conditions. https://doi.org/10.31234/osf.io/68pfx, Erişim Tarihi: 18.11.2021.

Türk, E. (2020). COVID-19 'un Çocuklar, Ergenler ve Yetişkinler Üzerindeki Psikolojik Etkileri Hakkında Derleme Çalışması, ResearchGate, COVID-19’un Çocuklar, Ergenler ve Yetişkinler Üzerindeki Psikolojik Etkileri Hakkında Derleme Çalışması, https://www.researchgate.net/publication/347262728; Erişim Tarihi: 25.10.2021.

United Nations (2020). Policy Brief: COVID-19 and the Need for Action on Mental Health: 13 May1s 2020, https://unsdg.un.org/ sites/default/files/2020-05, Erişim Tarihi: 27.10.2021.

WHO World Health Organization. WHO Coronavirus (COVID-19) Dahshboard. https://covid19.who.int/table. Erişim Tarihi: 24.10.2021.

Yue, J., Zang, X., Le, Y., An, Y. (2020). Anxiety, depression and PTSD among children and their parent during 2019 novel coronavirus disease (Covid 19) outbreak in China, Current Psychology. Published:14 November 2020, https://link.springer. com/article/10.1007\%2Fs12144.020.01191-4, Erişim Tarihi: 27.10.2021. 


\section{Effects of Covid 19 Pandemic on Children}

Oktay AYDIN

\section{Introduction and purpose}

The Covid 19 pandemic has brought about many problems all over the world including Turkey. Children have been among the biggest victims of the crisis. In this period when approximately 18 million children (MoNE Department of Strategic Development,2021) were actively enrolled in education at kindergarten, primary, secondary and high school levels, children who were not able to go to school had to conduct their educational processes over computer based systems. These processes have made such an effect that they almost changed the meaning of education, differentiating the roles of teachers, parents and students.

Some of the problems faced in homes and educational settings upon the entrance of the Covid 19 virus in our lives are as follows:

* Learning-teaching processes have been transferred to digital platforms and teaching processes have become more challenging.

* Methods and techniques of measurement-assessment concerning students' gains have been hindered.

* Students' problems with class participation, doing homework and studying tasks have increased.

* Teachers' teaching skills remained insufficient to fulfil their duties.

* Parents have had to take more part in the processes concerning their children, which increased their workload.

It is necessary to know the effects of the pandemic especially on children and the experiences of children during this period. In the upcoming years, experts will be offering different solutions to educational problems in the light of this information. Based on this fact, the present study aimed to determine the effects of the Covid-19 pandemic on children's daily habits, moods and behaviours towards distance education.

\section{Literature review}

The coronavirus pandemic first broke out in Wuhan, the capital of China's Hubei province, on December 1, 2019 and spread in Europe, North America and Asian Pacific over time through transmission from person to person. Upon the increased rate of spread of the virus in January 2020, the World Health Organization declared the novel coronavirus a global pandemic on 11 March 2020 (Vikipedi, 2021).

The Covid 19 pandemic has been among the most critical problems faced by the world in recent years. Creating a massive trauma effect all around the world, the pandemic has caused negative outcomes in many fields. Because of the pandemic leaving deep scars in the social and economic world, people's daily lives, habits, behaviour patterns and relationships have changed at an unexpected level. One of the fields most severely affected by the pandemic has been education.

According to the World Bank's evaluations made using the data on 157 countries, school closures due to Covid-19 
have left over one billion students outside the school. This reveals the fact that schooling and learning will fall at a global level. Moreover, it is suspected that nearly 7 million students from primary education to secondary education may quit school only because of the income shock caused by the pandemic. It is highlighted that a school shutdown of 5 months could generate learning losses of 10 trillion dollars globally (The World Bank, 2021).

The pandemic has obviously had negative effects on all groups. However, such factors as the economic and social effects of the pandemic on families, long periods of quarantine and social isolation, problems faced in access to distance education and unreported domestic violence show that children are among the vulnerable age groups affected by the pandemic (Akkan, 2020). As a matter of fact, schools have been closed in 188 countries because of the Covid-19 pandemic and $90 \%$ of the world's students have been affected negatively (Lee, 2020). Such disasters are much likely to have short and long-term effects on children's psychological functioning, emotional adaptation, health and developmental lines (Schonfeld and Demaria, 2015). In this period, the amount of true and unfounded information shared has increased in news sources, which has caused significant stress among children, adolescents and adults (Türk, 2020).

\section{Methodology}

The study group consisted of 876 parents of students attending $1^{\text {st }}-4^{\text {th }}$ grades in primary school and $5^{\text {th }}-8^{\text {th }}$ grades in secondary school. 749 of the parents are mothers, 116 are fathers; 443 of them have sons and 433 have daughters.

The data were collected using the questionnaire form developed by the researcher. The questionnaire consists of 4 sections and 16 questions. The questions are about children's daily lives in the first section, their moods in the second section, social relationships in the third section and their behaviours towards distance education in the fourth section.

\section{Results, conclusion and suggestions}

Results concerning children's daily live habits during the pandemic

* Children's sleep patterns have changed rather negatively compared with the times before the pandemic. Sleep patterns of students attending state schools have been more adversely changed compared with their peers attending private schools.

* Children's eating patterns have changed negatively compared with the pre-pandemic period. Eating patterns of children attending secondary school have changed more negatively than those of children attending primary school.

* Children's behaviours of getting dressed and undressed have changed at a remarkably negative level compared with the pre-pandemic period. Negative changes are more commonly observed among children enrolled in private schools while positive changes are observed more commonly among children attending state schools. In terms of educational levels, it is seen that negative changes have occurred among secondary school students whereas positive changes have been seen among children attending primary school.

* Children's cleaning habits have obviously changed in a positive direction compared with the pre-pandemic period. Cleaning habits of children attending state schools have changed more positively than those of children attending private schools. Compared in terms of educational levels, positive changes have occurred in the cleaning habits of primary school students more apparently compared with children attending secondary school. Negative changes, on the other hand, have been observed more among secondary school students.

Results concerning the effects of the pandemic on children's moods

* Children's anxiety levels increased considerably compared with the pre-pandemic period.

* Children's levels of anger have increased considerably compared with the pre-pandemic period.

* Children's levels of fears have increased considerably compared with the pre-pandemic period. Levels of fears of children attending state schools have increased more than those of children attending private schools.

* Children's happiness (joy) levels have decreased considerably compared with the pre-pandemic period. Happiness levels of children attending state schools have decreased more than those of children attending private schools. Happiness levels of secondary school students seem to have decreased more than those of children attending primary school. 
Results concerning the effects of the pandemic on children's social relationships

* Most of the children have built more negative relationships with their mothers (reactive, introverted, less communication, displaying changeable behaviours etc.) compared with the pre-pandemic period. Children going to private schools had more negative communication compared with children attending state schools. In addition, secondary school students developed more negative communication than children going to primary school.

* A remarkable number of children have built more negative relationships with their fathers (reactive, introverted, less communication, displaying changeable behaviours etc.) compared with the pre-pandemic period. Most of the children building negative communication are those who attend private schools. Additionally, children attending secondary school had more negative communication compared with primary school students.

* A remarkable number of children have built more negative relationships with their sibling(s) (reactive, introverted, less communication, displaying changeable behaviours etc.) compared with the pre-pandemic period. Most of the children building negative communication are girls. Moreover, children going to state schools built more negative communication than those going to private schools.

* More than half the students seem to have missed their teachers. Most of the children who missed their teachers are girls. In terms of educational level, it is understood that children attending primary school missed their teachers more than secondary school students did.

Results concerning the effects of the pandemic on children's behaviours towards distance education

* It is concluded that almost three-fourths of children were more or less unable to sufficiently adapt to distance education. When the sub-groups are compared, it is seen that adaptation problems are more common among boys than girls, among children attending state schools than those going to private schools and among secondary school students than primary school students.

* A considerably high number of children attended distance education regularly. It is seen that one out of ten children had problems in attending distance education. When the sub-groups are compared in terms of children having problems, it is seen that more problems have been faced by children going to state schools than those going to private schools and by secondary school students than primary school students.

* It was found that more than half the children had poor learning quality. In the sub-group comparisons, children who had extreme values over the options and experienced the problem constantly were rather those who attended state schools. Also, students attending secondary school seem to have experienced more learning problems than primary school students.

* Nearly half the children had problems in doing homework in the distance education process. According to the comparisons of the sub-groups, children attending state schools had more trouble in doing homework. In addition, it is seen that secondary school students had more problems with homework compared with children attending primary school.

The following recommendations could be guiding to eliminate the negative effects of the Covid 19 pandemic:

* Supportive training should be considered and planned for families at schools to make children adapt to the post-pandemic periods.

* Through the development of intervention programs by guidance units at schools, support should be given to the solution of children's such problems as school adaptation, dealing with anxiety, anger control and conflict resolution.

* Supportive programs should be developed for the solution of the problem by non-governmental organizations and they should be put into practice through cooperation with various institutions.

* Considering the fact that distance education will become a part of formal education and hybrid education will gain continuity, development of online education platforms should be continued by extending over time. The development of such technologies should benefit from the information on effective teaching models and methods. 
* Preventive and promoting activities should be organized, social events should be held and sharing should be allowed in dramatized settings to solve possible problems among peers at schools.

* Detailed studies should be conducted to compare the characteristics of the groups that are positively and negatively affected by the pandemic. 